\title{
AMMONIA EMISSION INVENTORY FOR THE STATE OF WYOMING
}

\author{
Prepared for Susan Caplan \\ Bureau of Land Management \\ Department of Interior \\ by \\ Thomas W. Kirchstetter \\ TWKirchstetter@lbl.gov \\ Colette R. Maser \\ CRMaser@lbl.gov \\ Nancy J. Brown, Principal Investigator \\ NJBrown@lbl.gov
}

Atmospheric Sciences Department

Lawrence Berkeley National Laboratory

Berkeley, California 94720 


\section{ABSTRACT}

Ammonia $\left(\mathrm{NH}_{3}\right)$ is the only significant gaseous base in the atmosphere and it has a variety of impacts as an atmospheric pollutant, including the formation of secondary aerosol particles: ammonium sulfate and ammonium nitrate. $\mathrm{NH}_{3}$ preferentially forms ammonium sulfate; consequently ammonium nitrate aerosol formation may be limited by the availability of $\mathrm{NH}_{3}$. Understanding the impact of emissions of oxides of sulfur and nitrogen on visibility, therefore, requires accurately determined ammonia emission inventories for use in air quality models, upon which regulatory and policy decisions increasingly depend.

This report presents an emission inventory of $\mathrm{NH}_{3}$ for the state of Wyoming. The inventory is temporally and spatially resolved at the monthly and county level, and is comprised of emissions from individual sources in ten categories: livestock, fertilizer, domestic animals, wild animals, wildfires, soil, industry, mobile sources, humans, and publicly owned treatment works. The Wyoming $\mathrm{NH}_{3}$ inventory was developed using the Carnegie Mellon University (CMU) Ammonia Model as framework. Current Wyoming-specific activity data and emissions factors obtained from state agencies and published literature were assessed and used as inputs to the CMU Ammonia Model.

Biogenic emissions from soils comprise about three-quarters of the Wyoming $\mathrm{NH}_{3}$ inventory, though emission factors from soils are highly uncertain. Published emission factors are scarce and based on limited measurements. In Wyoming, agricultural land, rangeland, and forests comprise $96 \%$ of the land area and essentially all of the estimated emissions from soils. Future research on emission rates of $\mathrm{NH}_{3}$ for these land categories may lead to a substantial change in the magnitude of soil emissions, a different inventory composition, and reduced uncertainty in the inventory.

While many $\mathrm{NH}_{3}$ inventories include annual emissions, air quality modeling studies require finer temporal resolution. Published studies indicate higher emission rates from soils and animal wastes at higher temperatures, and temporal variation in fertilizer application. A recent inverse modeling study indicates temporal variation in regional $\mathrm{NH}_{3}$ emissions. Monthly allocation factors were derived to estimate monthly emissions from soils, livestock and wild animal waste based on annual emission estimates. Monthly resolution of $\mathrm{NH}_{3}$ emissions from fertilizers is based on fertilizer sales to farmers. Statewide $\mathrm{NH}_{3}$ emissions are highest in the late spring and early summer months. 


\section{INTRODUCTION}

Ammonia $\left(\mathrm{NH}_{3}\right)$ is the third most abundant nitrogen gas and is the only significant gaseous base in the atmosphere. $\mathrm{NH}_{3}$ has a short atmospheric lifetime of hours to days, but has a wide variety of impacts as an atmospheric pollutant. Among them are eutrophication of terrestrial and aquatic ecosystems and soil acidification, which leads to forest decline (Bouwman and Van Der Hoek, 1997). Along with sulfur oxides $\left(\mathrm{SO}_{\mathrm{x}}\right)$ and nitrogen oxides $\left(\mathrm{NO}_{\mathrm{x}}\right), \mathrm{NH}_{3}$ is a major precursor of secondary aerosol particles formed by gas phase reactions in the atmosphere. $\mathrm{SO}_{\mathrm{x}}$ and $\mathrm{NO}_{\mathrm{x}}$ react with oxidants in the atmosphere and water to form sulfuric and nitric acid aqueous aerosols. Ammonia serves an important role in neutralizing these acids by converting the particles to ammonium sulfate and ammonium nitrate. While lowering atmospheric acidity, these ammoniated aerosol products scatter light efficiently and degrade visibility. Ammonium sulfate and nitrate contribute significantly to fine particle matter $\left(\mathrm{PM}_{2.5}\right)$ mass concentration and visibility reduction in many regions of the United States (Sisler and Malm, 1994). Knowledge and possible curtailment of ammonia emissions is, therefore, important for compliance with the National Ambient Air Quality Standard for $\mathrm{PM}_{2.5}$ and the Regional Haze Rule for visibility in Class 1 areas.

The formation of nitrate aerosol may be limited by the availability of $\mathrm{NH}_{3}$. Ammonia preferentially reacts to form non-volatile ammonium sulfate, and if excess $\mathrm{NH}_{3}$ is present after reaction with sulfuric acid, $\mathrm{NH}_{3}$ then reacts with $\mathrm{NO}_{\mathrm{x}}$ to form ammonia nitrate (Dentener and Crutzen, 1994). Unlike ammonium sulfate, ammonium nitrate is volatile and the gas/particle partitioning of ammonium nitrate is a strong function of temperature and relative humidity. In regions of high sulfate concentration or low emission of $\mathrm{NH}_{3}$, the atmosphere may be in an ammonia limited regime in regard to nitrate formation.

Much of the modeling of this inorganic aerosol system has been performed in areas of the country where the concentrations of $\mathrm{NH}_{3}$ do not limit particle formation, primarily in the Southern California and San Joaquin Valley air basins in California. These conditions may not exist, however, in the inter-mountain west. For example, emissions estimates of $\mathrm{NH}_{3}$ for San Joaquin Valley County in California are 5.04 tons $/ y e a r / \mathrm{km}^{2}$ while those in Sublette County in Wyoming are approximately 0.069 tons/year $/ \mathrm{km}^{2}$ (EarthTech, 1998; Benjamin, 2001). The EPA estimated that the states of California and Wyoming are the seventh and thirty-third largest emitters in the U.S. (EPA, 2000), respectively, as illustrated in Figure 1.

Understanding the impact of emissions of $\mathrm{SO}_{\mathrm{x}}$ and $\mathrm{NO}_{\mathrm{x}}$ on visibility in the West requires an accurately determined ammonia emission inventory comprised of a variety of source types. The inventory is essential for predicting concentrations of ammonium sulfate and ammonium nitrate aerosols in visibility models, confirming whether or not the inorganic aerosol system is in equilibrium, and for identifying the limiting reagent if one should exist. Regulatory and policy 
decisions increasingly depend upon modeling, therefore it is important to ensure that particle formation models perform correctly in this region of the country where emission patterns and chemistry are quite different from the more thoroughly-studied urban areas.

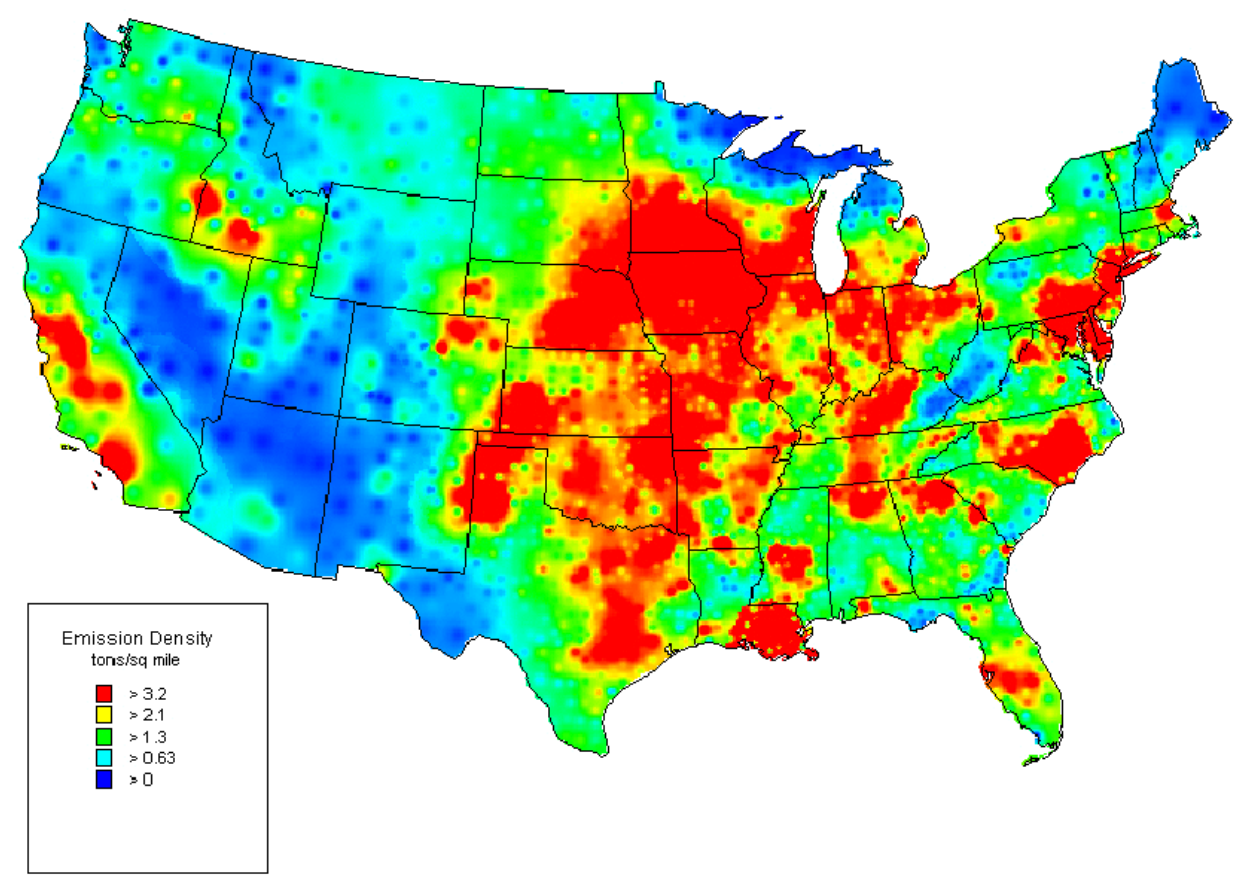

Figure 1. Map of estimated $\mathrm{NH}_{3}$ emissions in the United States (EPA, 2002).

Ammonia emission inventories contain many more uncertainties than the emission inventories of $\mathrm{SO}_{\mathrm{x}}$ and $\mathrm{NO}_{\mathrm{x}}$, which have long been examined with great scrutiny because of their immediate health effects and roles in acid rain and ozone formation. Also, most $\mathrm{SO}_{\mathrm{x}}$ and a significant portion of $\mathrm{NO}_{\mathrm{x}}$ emissions are from major point sources that are easily monitored, whereas ammonia is emitted from an array of urban and rural sources, many of which are diffuse and/or unregulated. While rural sources may dominate ammonia emissions across large areas, on a smaller scale, urban sources may be more influential since the formation of secondary aerosols requires the coexistence of $\mathrm{NH}_{3}$ and $\mathrm{SO}_{\mathrm{x}}$ or $\mathrm{NO}_{\mathrm{x}}$. Therefore, the accuracy of $\mathrm{NH}_{3}$ emissions estimates for sources that co-emit $\mathrm{SO}_{\mathrm{x}}$ or $\mathrm{NO}_{\mathrm{x}}$, or emit into ambient plums of $\mathrm{SO}_{\mathrm{x}}$ or $\mathrm{NO}_{\mathrm{x}}$, is more important than their absolute magnitudes might suggest. For example, livestock and fertilizer application leads to significant $\mathrm{NH}_{3}$ emissions, but they are generally farther removed from $\mathrm{SO}_{\mathrm{x}}$ and $\mathrm{NO}_{\mathrm{x}}$ sources than are urban sources.

Little is currently known about ammonia emissions and concentrations in the intermountain region. Worldwide, waste from livestock is estimated to be the largest sources of ammonia (Bouwman et al., 1997). Other significant sources include fertilizer use, biomass 
burning, soils and human wastes (Bouwman et al., 1997). These estimates are based largely on emission factors developed in Europe by Asman (1992), and are understood to contain large uncertainties. An ammonia inventory compiled for a modeling study of Southwest Wyoming includes no estimate of (EarthTech, 1998) emissions from industrial processes, diesel engines, or wood burning - all of which could be substantial sources in some areas. For non-urban, nonagricultural areas, the importance of soil and other biogenic emissions (those not caused by human activities) may also be important for understanding local air quality.

The purpose of this study is to develop an ammonia emission inventory for the state of Wyoming based on the most current information about sources and source activity. To facilitate the development of the inventory, we used the Carnegie Mellon University Ammonia Model (CMU, 2003) as a framework. The CMU model is a downloadable computer program that references user-adaptable emission factor and activity files to create the emission inventory. Other inventories of $\mathrm{NH}_{3}$ emissions in Wyoming (EPA, 2002; WRAP, 2001) are not user accessible in this manner and therefore do not allow one to make refinements as improved data become available.

This CMU Model has been designed to estimate $\mathrm{NH}_{3}$ emissions resolved to the county level in each of the continental Unites States. It is recommended that the default emission factor and activity data be evaluated and modified when needed when applying it to individual states (Strader, 2003). In this study, we reviewed all available emission factor and activity level data specific to the state of Wyoming.

The CMU Model accounts for ammonia emissions from 82 individual sources that comprise ten categories: livestock, fertilizer, mobile sources, domestic animals, wild animals, wildfires, soil, industry, humans, and publicly owned treatment works (POTWs). Application of the CMU Model to Wyoming using the default values for emission factors and activity levels yields a statewide emission estimate of $1.20 \times 10^{8} \mathrm{~kg} \mathrm{NH}_{3}$ year ${ }^{-1}$. Biogenic emissions of $\mathrm{NH}_{3}$ from soils constitute $77 \%$ of the inventory, but the developers of the CMU Model and others acknowledge that emission factors from soils are highly uncertain. The estimated inventory total, soil emissions excluded, is $2.81 \times 10^{7} \mathrm{~kg} \mathrm{NH}_{3}$ year $^{-1}$. The distribution of emissions is illustrated in Figure 1. In this case, livestock and fertilizer represent the largest sources, together constituting $83 \%$ of the total inventory. Emissions from cattle constitute the overwhelming majority (90\%) of emissions from livestock. This is consistent with other inventories for South Korea (Lee and Park, 2002), the United Kingdom (Pain et al., 1998) and the United States (Battye et al., 1994). Emissions associated with three of the thirteen types of fertilizers account for a great majority (86\%) of total emissions from this category. Thus, statewide, the emissions distribution is highly skewed. Source categories that contribute less than $2 \%$ of total $\mathrm{NH}_{3}$ emissions are wildfires, domestic animals, humans, and POTWs. 
The CMU Model employed in this study (version 3.0 Public Beta) was released in April of 2003. Compared to its predecessor (version 2.1), the default emission factor dataset included with the current version has been updated. Twenty-eight emission factors were revised, which resulted in a 50\% decrease in statewide estimated $\mathrm{NH}_{3}$ emissions in Wyoming. Decreases in emission factors for livestock animals, most notably those of cattle, represented $77 \%$ of the decrease in the statewide inventory. Changes to emission factors associated with fertilizer application represented $12 \%$ of the decrease in the inventory. This illustrates the skewed nature of $\mathrm{NH}_{3}$ emissions statewide, wherein emissions from cattle and fertilizer application are dominant, and the inventory is particularly sensitive to large changes in emission factors and activity levels for these sources. In a review of the earlier CMU Model (version 2.1), recommendations were made for updating several of the default emission factors (Chinkin et al., 2003). Notably, the reduced emission factors for cattle incorporated into the present version of the CMU Model are the same as those recommended by Chinkin et al. (2003).

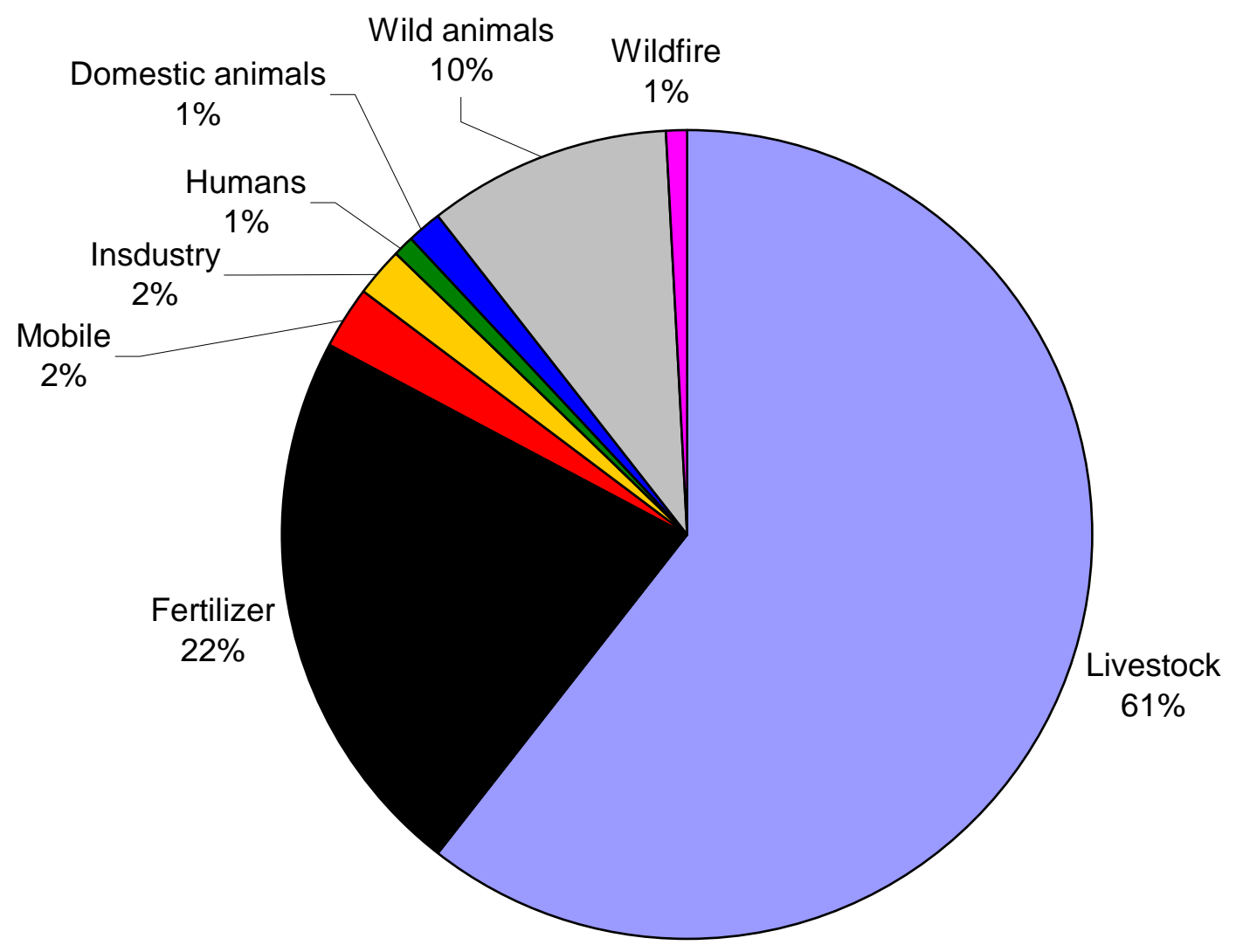

Figure 2. Contributions from different source categories (excluding soils) to the statewide $\mathrm{NH}_{3}$ emission inventory in Wyoming derived using the CMU Model with default parameters (CMU, 2003). 
In the next section of this report, we discuss the emission factors and activity files that we used as inputs to the CMU Model framework. In our review of emission factors, we consider the recent review of Chinkin et al. (2003), the recent updates to the default values in the CMU Model, and other published data. The most recent activity data specific to the counties in Wyoming was incorporated. Tabulated emission factors and activity data are presented in the report Appendices A and B. 


\section{EMISSION FACTORS AND ACTIVITY}

\section{Livestock Emissions}

Emission of $\mathrm{NH}_{3}$ from livestock is estimated to be one of the largest sources of ammonia in the U.S. (EPA, 2000) and worldwide (Bouwman, 1997). In this study, we considered emissions from the 16 animal types listed below in Table 1. As mentioned earlier, cattle (milk cows, beef cows, heifers, and steers) comprise the overwhelmingly dominant source of livestock related emission of $\mathrm{NH}_{3}$.

Table 1. Animals included in the livestock category of the Wyoming $\mathrm{NH}_{3}$ inventory.

\begin{tabular}{lll}
\hline Cattle & Other animals & Fowl \\
\hline milk cows & hogs and pigs & geese \\
beef cows & horses & ducks \\
heifers & angora goats & turkeys \\
steers & milk goats & broilers \\
& sheep & pullets, < 13 wks \\
& & pullets, 13 to 20 wks \\
& & layers (pullets $>20 \mathrm{wks})$ \\
\hline
\end{tabular}

The emission factors used to estimate $\mathrm{NH}_{3}$ for most livestock animals (cattle, horses, sheep, goats, and chickens) are those developed by Bouwman et al. (1997) for developed countries. Bouwman et al. developed emission factors for developed and developing countries to account for the regional differences in feeding situations, animal characteristics and management conditions. Bouwman et al. calculated emission rates of $\mathrm{NH}_{3}$ from domestic animal waste based on average nitrogen excretion from different animals and subsequent $\mathrm{NH}_{3}$ losses during housing, storage of wastes outdoors, grazing, and application of the wastes to grassland or arable land.

We note that the cattle emission factors recommended by Bouwman et al. and used in this study are the emission factors newly adopted in the CMU Model, recently recommended by Chinkin et al. (2003), and previously suggested to the EPA by Battye et al. (1994). The emission factor for pigs used in this study is the default CMU Model emission factor, and is equal to that recommended by Chinkin et al. and similar to that suggested by Battye et al. The default values given in the CMU Model emission for the remainder of the livestock species (ducks, geese and turkeys) were used in this study. These were adopted from a report by the European Environmental Agency (2001). 
The USDA publishes livestock activity data (i.e., population estimates) at the county level in the Census of Agriculture every five years (USDA, 1997). The most recently available data were collected in 1997; year 2002 data are tentatively scheduled for publication in February 2004. Four cattle classifications are reported in the Census of Agriculture and have been incorporated into the CMU model: beef cows, milk cows, heifers, and steers. In addition to the USDA data, the Wyoming Agricultural Statistics Service (WASS) provides county estimates of total cattle population yearly; the most recent available data are for 2002 (WASS, 2002). The total cattle population estimates for 1997 in both reports agree well. We used the more recent population data from WASS to determine the relative change in each county's total cattle population from 1997 to 2002. Using this information, we derived population estimates for 2002 for the four cattle classes based on the 1997 USDA data. The scaling factors are listed below in Table 2. Most scaling factors were less than $\pm 30 \%$. It follows that the resultant activity levels and emission inventory assume that the populations of each of the four cattle classes varied by the same proportion between 1997 and 2002. These activity levels should be modified if needed when the next USDA census report is published. All other livestock activity levels are those of the 1997 Census of Agriculture.

Table 2. Scaling factors derived from Wyoming Agricultural Statistics Service total cattle data (WASS, 2002) and applied to 1997 USDA cattle class populations to estimate 2002 populations.

\begin{tabular}{lclc}
\hline County & $\begin{array}{c}\text { Cattle population } \\
\text { ratio, 1997/2002 }\end{array}$ & County & $\begin{array}{c}\text { Cattle population } \\
\text { ratio, 1997/2002 }\end{array}$ \\
\hline Albany & 0.79 & Natrona & 0.87 \\
Big Horn & 1.02 & Niobrara & 1.08 \\
Campbell & 1.01 & Park & 0.83 \\
Carbon & 0.83 & Platte & 1.33 \\
Converse & 1.18 & Sheridan & 0.79 \\
Crook & 0.70 & Sublette & 0.63 \\
Fremont & 0.91 & Sweetwater & 0.75 \\
Goshen & 1.16 & Teton & 0.75 \\
Hot Springs & 1.08 & Uinta & 0.70 \\
Johnson & 0.81 & Washakie & 0.76 \\
Laramie & 1.32 & Weston & 1.04 \\
Lincoln & 0.79 & & \\
\hline
\end{tabular}




\section{Fertilizer Emissions}

Ammonia is released into the atmosphere following application of nitrogen containing fertilizers. The volatilization of $\mathrm{NH}_{3}$ is related to the type of fertilizer, soil properties (e.g., soil $\mathrm{pH}$ and moisture content), meteorological conditions and management. Increased temperature, for example, promotes $\mathrm{NH}_{3}$ emission (Bouwman et al., 1997). Most ammonia emissions are released within a few days after application (Van der Weerden and Jarvis, 1997).

Several $\mathrm{NH}_{3}$ inventories that include emissions related to fertilizer application have been published. Goebes et al. (2003) developed the most recent inventory for the United States, and reviewed those previously published. Emission factors and activity levels (i.e., amount of fertilizer applied and time of application) developed by Goebes et al. were incorporated into the current CMU Model and used in this study.

The fertilizer emission factors of Goebes et al. (2003) are largely taken from Asman (1992). These have been used in other inventories as well (Bouwman et al., 1997; Battye et al., 1994). Asman's emission factors are based largely on the experiments of Whitehead and Raistrick (1990), who measured emissions during application of different fertilizers to various types of soil. The emission factors are reported in Appendix A of this report. Emission factors are reported for 14 fertilizer types: 13 types that comprise $>95 \%$ of all fertilizers used (Goebes et al., 2003) and a miscellaneous category that represents lesser-used fertilizers.

Fertilizer application (i.e., activity) is temporally, primarily linked to planting and harvesting in spring and fall, and spatially variable. Goebes et al. (2003) noted emissions might vary greatly within a state, and noted that fertilizer emissions in Wyoming are largely associated with agricultural activity in the southeast and northwest. Activity levels in the CMU Model based on 1995 fertilizer sales to farmers by county and type of fertilizer covering two six-month time periods (January to June and July to December). These data are taken from a report published by the American Plant Food Control Officials (AAPFCO, 1995). AAPFCO published a more recent 2002 Commercial Fertilizers report, however, the data for Wyoming is an estimate based on average usage from surrounding states (Terry, 2003). Therefore we did not modify the default activity levels in the CMU Model.

\section{Wild Animal Emissions}

Emissions from black and grizzly bears, deer and elk are included in the CMU Model. In this study we included antelope as well because their statewide population is close to that of deer (WYGF, 2003).

Wildlife $\mathrm{NH}_{3}$ factors are those of Warn et al. (1990), who presented yearly emission estimates derived from weight normalized emission rates and typical animal weights. Warn et al. reported a weight normalized emission rate for bears but not their weight; thus, they did not 
present emission factors for bears. We calculated emission factors for bears based on a weight of 550 lbs for grizzly bears (www.bear.org) and 200 lbs for black bears (www.americanbear.org). Our emission factors are compared in Table 3 to the default emission factors of the CMU Model. Also shown are wildlife waste emission factors reported by Benjamin (2003) for development of an $\mathrm{NH}_{3}$ emission inventory for the state of California.

Table 3. Wildlife animal $\mathrm{NH}_{3}$ emission factors $\left(\mathrm{kg} \mathrm{NH}_{3} \mathrm{yr}^{-1}\right)$ used in this study versus the default values in the CMU Model.

\begin{tabular}{lrcc}
\hline Wildlife Animal & This study & $\begin{array}{c}\text { CMU Model default } \\
\text { values }\end{array}$ & Benjamin (2003) \\
\hline Black bear & 66.1 & 4.6 & 19.1 \\
Grizzly bear & 181.8 & 4.6 & \\
Deer & 4.8 & 4.6 & 5.1 \\
Elk & 17.2 & 24.5 & 17.2 \\
Antelope & 2.9 & n/a & 2.9 \\
\hline
\end{tabular}

Estimates of deer, elk and antelope population were available from Wyoming Game and Fish Department (WYGF, 2003) for the end of the 2001 hunting season, which means the data are valid for early 2002. Population estimates were given for herd groups. Herd groups are not defined by county lines but are grouped by hunt area. Therefore, we used a hunt area map (gf.state.wy/wildlife/application/nonres_03.asp) to determine which county or counties a specific herd group occupied. The population of a herd group was divided evenly if it covered two or more counties. Activity levels for black and grizzly bears more recent than those in the default CMU Model files (valid for 1993) were not available from either Wyoming Game and Fish or the American Bear Association. Therefore, no modifications were made to these activity levels.

\section{Mobile Source Emissions}

Catalytic converters, designed to reduce $\mathrm{NO}_{\mathrm{x}}$ emissions from gasoline-powered vehicles, produce ammonia emissions as a by-product of $\mathrm{NO}_{\mathrm{x}}$ conversion. To estimate mobile source emissions of ammonia, it is necessary to distinguish between activity of vehicles equipped and not equipped with catalytic converters. The Wyoming Department of Transportation (WYDOT, 2003) provided us with the number of vehicle miles driven per county in year 2002 for all onroad vehicles, broken down into thirteen classes: motorcycles, passenger cars, two-axle four-tire single units, buses, two-axle six-tire single units, three-axle single units, four or more axle single units, four or less axle single trailers, five-axle single trailers, six or more axle single trailers, five or less axle multi-trailer, six-axle multi-trailer and seven or more axle multi-trailer. We assigned 
these classes to one of two groups: those that could be catalyst equipped and those not catalyst equipped. Motorcycles were not included in either group. Passenger cars, two-axle four-tire single unit vehicles and two-axle six-tire single unit trucks were assigned to the first category since these vehicle types include light and medium duty gasoline powered vehicles, many of which are catalyst equipped. The remaining ten vehicle classes were assigned to the non-catalyst equipped group.

Durbin et al. (2002) reported $\mathrm{NH}_{3}$ emission rates for a fleet of 39 in-use light duty gasoline-fueled vehicles consisting of cars and trucks with various levels of emission controls ranging from non-catalyst vehicles to those certified at the ULEV California standard, all of which were driven on dynamometers following the Federal Test Procedure. The emission rate averaged $54 \mathrm{mg} \mathrm{mi}^{-1}$. The factors for pre-1990 and post 1990 (Tier 0 and Tier 1 ) vehicles were, respectively 12 and $75 \mathrm{mg} \mathrm{mi}^{-1}$. A subset of tests indicated that $\mathrm{NH}_{3}$ emissions increased with more aggressive driving conditions. $\mathrm{NH}_{3}$ emissions typically occurred after catalyst light-off when the catalyst approached its equilibrium temperature.

Table 4. Summary of $\mathrm{NH}_{3}$ emission factors for motor vehicles.

\begin{tabular}{lll}
\hline Reference & EF $\left(\mathrm{mg} \mathrm{NH}_{3} \mathrm{mi}^{-1}\right)$ & \multicolumn{1}{c}{ Vehicle Type } \\
\hline Bouwman et al. 1997 & 117 & $\begin{array}{l}\text { catalyst equipped light duty gasoline } \\
\text { diesel vehicles }\end{array}$ \\
& 5.9 & non catalyst equipped light duty gasoline \\
& 2.0 & catalyst equipped LD \\
Fraser and Cass, 1998 & 116 & mixed fleet \\
& 98 & diesel (assumed) \\
Kean et al., 2000 & $78 \pm 5$ & 95\% catalyst equipped, 99\% gasoline LD \\
Durbin et al., 2002 & $54($ range $<4$ to 177) & mixed LD fleet \\
CMU default values & 97 & cars \\
& 27 & trucks \\
This study & 80 & gasoline catalyst equipped group \\
& 5 & non-catalyst group \\
\hline
\end{tabular}

The tunnel study of Kean et al. (2000) indicated an average 1999 in-use fleet emission rate of $79 \mathrm{mg} \mathrm{mi}^{-1}$. It was estimated that $99 \%$ and $95 \%$ of the vehicles under study in the Caldecott tunnel were gasoline-powered and catalyst-equipped, respectively. Bouwman et al. 
(1997) referenced two European studies for use in their global emission inventory and reported $\mathrm{NH}_{3}$ emission rates of 2.0, 117, $5.9 \mathrm{mg} \mathrm{mi}^{-1}$ for uncontrolled petrol-engine cars, three-way catalyst cars and diesel vehicles, respectively. From the 1993 Van Nuys tunnel study, Fraser and Cass (1998) reported an emission rate of $98.1 \mathrm{mg} \mathrm{NH} / \mathrm{mi}$ for the observed fleet, $91.8 \%$ of which were gasoline powered and catalyst equipped. They estimated a value of $116 \mathrm{mg} \mathrm{NH} / \mathrm{mi}_{\text {for the }}$ only three-way or dual-bed catalyst equipped vehicles assuming negligible (i.e., zero) emissions from diesel vehicles in the fleet.

The emission factors used in this study are based on the review of Bouwman et al. (1997), Fraser and Cass (1998), Kean et al. (2000) and Durbin et al. (2002) and the factors used by the CMU Model (Table 4). Based on this review, we chose emission factors of 80 and $5 \mathrm{mg}$ $\mathrm{mi}^{-1}$ for our catalyst and non-catalyst equipped vehicle groups.

\section{Wildfire Emissions}

Emissions of $\mathrm{NH}_{3}$ from burning biomass are dependent on the nitrogen content of the fuel (Bouwman et al., 1997), which is known to vary from 0.1 to almost $5 \%$ by mass and changes significantly over the course of a year as vegetation cures (Yokelson, 2003). Further, the conditions of the fire, whether smoldering or flaming, impact $\mathrm{NH}_{3}$ emission rates (Yokelson, 2003). $\mathrm{NH}_{3}$ is produced mainly during the smoldering process whereas $\mathrm{NO}_{\mathrm{x}}$ is emitted under flaming fire conditions.

Goode et al. (2000) presented average carbon monoxide (CO) emission factors and $\mathrm{NH}_{3} / \mathrm{CO}$ emission rates measured for a large number of fires. Most of the forests in Wyoming are comprised of aspen, Engelmann spruce, Douglas fir, alpine fir, white bark, limber pine and lodge pole pine (WY Tourism, 2003). These biomass types are represented in the studies reviewed by Goode et al. (2000). CO emission factors range from 81.6 to $96.5 \mathrm{~g} \mathrm{~kg}^{-1}$ of wood burned, and $\mathrm{NH}_{3} / \mathrm{CO}$ ratios range from 0.0122 to 0.0257 for the studies reviewed. For this study, we chose central values of the molar emission ratio $\mathrm{NH}_{3} / \mathrm{CO}(0.02)$ and the $\mathrm{CO}$ emission factor $\left(90 \mathrm{~g} \mathrm{~kg}^{-1}\right)$.

Biomass burning activity data employed in this study is the same as in the CMU Model. These data include the number of acres burned, supplied by the National Interagency Fire Center (NIFC, 2000), and the fuel loading per acre (EPA, 2000). More recent data from the Wyoming State Forestry Division are not reconcilable with the data from NIFC and are not available at the county level, and were not used here. However, starting with the 2003 fire season each county will have a computer reporting system, so future data on acreage burned will likely be more reliable. 


\section{Industrial Process Emissions}

The EPA maintains a database of $\mathrm{NH}_{3}$ emissions that is part of the Toxic Release Inventory (TRI). States report emissions at the county level. The contribution of industrial emissions to the Wyoming $\mathrm{NH}_{3}$ inventory was obtained directly from the TRI rather than through multiplication of emission factors by activity levels. The current CMU Model includes industrial emissions for 1995. Rather than use these default values, we used more recent data for 2001 that is published in the online TRI (www.epa.gov/tri). Industrial $\mathrm{NH}_{3}$ emissions are reported for nine of the 23 Wyoming counties, as shown below in Table 5.

Statewide industrial $\mathrm{NH}_{3}$ emissions decreased from 606 to 267 metric tons between 1995 and 2001, due in large part to the $>60 \%$ reduction reported for Laramie county. Carbon and Sweetwater Counties reported increased industrial $\mathrm{NH}_{3}$ emissions.

Table 5. Year 1995 and 2001 industrial air emissions of $\mathrm{NH}_{3}\left(\mathrm{~kg} \mathrm{yr}^{-1}\right)$ reported in the EPA Toxic Release Inventory.

\begin{tabular}{lrr}
\hline County & 1995 & 2001 \\
\hline Big Horn & 799 & 5060 \\
Campbell & 0 & 2 \\
Carbon & 1637 & 4396 \\
Goshen & 50794 & 25541 \\
Laramie & 475236 & 169560 \\
Lincoln & 17551 & 1682 \\
Natrona & 2550 & 448 \\
Sweetwater & 14535 & 22818 \\
Washakie & 42630 & 37409 \\
Total: & $\mathbf{6 0 5 7 3 2}$ & $\mathbf{2 6 6 9 1 6}$ \\
\hline
\end{tabular}

\section{Publicly Owned Treatment Work (POTW) Emissions}

Municipal sewage treatment plants process sufficient quantities of nitrogen-rich wastes to generate significant ammonia emissions under certain conditions. As of 1996, there were 103 facilities in operation in Wyoming. The volume of wastewater treated (i.e., activity) is compiled by the EPA and available online (EPA, 1996). These are the data in the CMU Model and used in this study. Statewide volume treated in 1996 was 50 million gallons. Newer data may become available as the EPA Office of Wastewater Management modernizes its database. The $\mathrm{NH}_{3}$ emission factor (19 lb Mgal ${ }^{-1}$ ) was developed for the National Acid Precipitation Assessment Program (Battye et al., 1994). It is based on influent and effluent $\mathrm{NH}_{3}$ concentrations from $>850$ 
wastewater treatment facilities and research on $\mathrm{NH}_{3}$ stripping (Warn et al., 1990) from treatment facilities. In their review of the CMU Model, Chinkin et al. (2003) noted that the emission factor is uncertain because of the assumptions made in its derivation.

\section{Human Emissions}

Ammonia is released from the breath, sweat, and excretion of humans as a normal metabolic process (Ament et al., 1997; Silvester et al., 1997; Spanel et al., 1998). These emissions generally comprise a minor portion of regional ammonia emissions and are not explicitly included in the EPA's air pollutant emission inventory (EPA, 2000). The CMU Model uses the emission factor recommended by Battye et al. (1994), which is comparable to that suggested by others (Bouwman et al., 1997). We found no basis for changing this emission factor; however, we updated the default CMU Model estimates of 1997 human population to 2002 populations, which the US Census Bureau estimated based on 2000 census data (US Census, 2000).

\section{Domestic Animal Emissions}

Emissions from dogs and cats are included in the inventory. They generally contribute negligibly to regional $\mathrm{NH}_{3}$ emissions. The default values for activity levels and emission factors in the CMU Model, obtained from the American Veterinary Medical Association (AVMA, 1997) and Battye et al. (1994), were not modified.

\section{Biogenic Soil Emissions}

Ammonia is produced naturally in soil by bacteria. Natural ecosystems are at equilibrium between atmospheric nitrogen and the nitrogen in the ground and, therefore, $\mathrm{NH}_{3}$ fluxes are related to the biological activity of the soil (Bouwman et al, 1997). Estimates of $\mathrm{NH}_{3}$ emissions from soils are debatable because emission factors are scarce and highly uncertain. Some studies suggest that soils can either be a net source or sink of $\mathrm{NH}_{3}$ (Roe and Mansell, 2001). High $\mathrm{pH}$ and low soil moisture content favor soil $\mathrm{NH}_{3}$ emissions because dry soils exhibit higher gas diffusivity than moist soil and high $\mathrm{pH}$ (alkaline soil) shifts the acid-base equilibrium in soil from ammonium ion to ammonia. Anderson et al. (2002) evaluated ammonia emissions in Texas and demonstrated the sensitivity of $\mathrm{NH}_{3}$ emissions to soil $\mathrm{pH}$ by noting a 20-fold reduction in $\mathrm{NH}_{3}$ emissions occurred when soil $\mathrm{pH}$ was reduced from six to five.

When ammonia emissions from soil are presented they often contribute significantly to the inventory. Thus, the fact that there is not a reliable method for estimating ammonia emissions from soil is a significant information gap in ammonia emission inventories. An estimate of $\mathrm{NH}_{3}$ emissions in the San Joaquin Valley in California (Coe et al., 1998) indicated that natural soils represented $42 \%$ of the total of annual inventory. Potter et al. (2001) recently used the NASA/CASA model to estimate native soil ammonia emissions for the entire state of 
California. Their yearly estimate of $3.7 \mathrm{Gg}$ is 20\% of EPA's estimate of total California $\mathrm{NH}_{3}$ emissions. Significant seasonal variations in emissions were predicted. As mentioned earlier, when soil emissions are included in the default CMU Model, they comprise $77 \%$ of the Wyoming $\mathrm{NH}_{3}$ inventory; seasonal variation is not incorporated. Soil emissions presented in this study are those of the CMU Model.

The CMU Model soil types (i.e., activity) are based on the United States Geological Survey land use and land cover data (EPA, 1994) that allowed land to be classified using a twotier system, called the Anderson classification system (Anderson et al., 1976). Anderson land use codes divide land into nine categories: urban, agricultural, rangeland, forest, water, wetland, barren, tundra, and perennial snow and ice. These categories are then divided further into more specific subcategories. As a check of accuracy, we added the total land area reported in the CMU Model for Wyoming and compared it with an independent source of land area (www.50state.com), and found that the figures agreed within $1 \%$.

As shown in Table 6, three soil categories, namely rangeland, forest, cropland/pasture, comprise $96 \%$ of the total land area in Wyoming. It follows that the accuracy of the emission rates of $\mathrm{NH}_{3}$ from soils in these categories will determines the accuracy of not only the soil inventory but also the overall inventory since, as mentioned above, soil emissions of ammonia are usually a significant portion of the total emission inventory.

Table 6. Dominant land uses (i.e., soil types) in Wyoming and published soil emission factors.

\begin{tabular}{|c|c|c|c|c|c|}
\hline \multirow[b]{2}{*}{$\begin{array}{l}\text { Land Use Category, } \\
\text { Subcategory }\end{array}$} & \multirow[b]{2}{*}{$\begin{array}{c}\% \text { of Land } \\
\text { Area }\end{array}$} & \multicolumn{4}{|c|}{ Emission Factors $\left(\mathrm{kg} \mathrm{NH}_{3} \mathrm{~km}^{-2} \mathrm{yr}^{-1}\right)$} \\
\hline & & CMU Model & $\begin{array}{c}\text { Chinkin et al., } \\
2003\end{array}$ & $\begin{array}{c}\text { Bouwman et al., } \\
1997\end{array}$ & $\begin{array}{l}\text { Potter et al., } \\
\qquad 2001^{\text {a }}\end{array}$ \\
\hline Rangeland: & 72 & & 14 & & \\
\hline herbaceous (19\%) & & 30.8 & & & \\
\hline shrub/brush (48\%) & & 30.8 & & 50 & \\
\hline mixed (33\%) & & 30.8 & & & \\
\hline Forest: & 18 & & & & \\
\hline deciduous (2\%) & & 11.7 & $2-400$ & 30 & $3-13$ \\
\hline evergreen 91\%) & & 11.7 & $1-40$ & & $1-16$ \\
\hline mixed (7\%) & & 11.7 & & & $1-21$ \\
\hline Cropland/Pasture & 6 & 100 & 0 & 0 & $9-22$ \\
\hline
\end{tabular}

a Potter et al. provide two estimates: assuming moderate $\mathrm{pH}$ effects (low estimate) and minimum $\mathrm{pH}$ effects (high estimate) 
Table 6 also presents a comparison of published emission factors, though direct comparison with other data is difficult due to its scarcity. A manuscript is in preparation discussing the CMU Model emission factors (Strader, 2003). Bowman et al. (1997) and Chinkin et al. (2003) suggested omitting $\mathrm{NH}_{3}$ emissions from cropland and pasture soils to avoid over counting emissions associated with livestock and fertilizer application on these lands. Chinkin et al. concluded that fertilizer $\mathrm{NH}_{3}$ emissions from cropland are expected to dominate the natural soil emissions. Strader (2003), however, argues that fertilizer emission factors typically capture only the initial $\mathrm{NH}_{3}$ spike released following fertilizer application, and not the long-term higher baseline emissions from the soil that are a result of the increased nitrogen content. In this regard, it is appropriate to have a non-zero soil emission factor for cropland/pasture, and indeed, it is usually higher than the unfertilized soil emission factor would be due to the increased nitrogen content of the soil. Further, Strader concludes that Chinkin et al. incorrectly interpreted the results of Potter et al. (2001) regarding baseline natural soil emissions for this soil subcategory. Indeed, Potter et al. estimated that $\mathrm{NH}_{3}$ emissions from native soil in California to be $12-57 \mathrm{Gg}$ $\mathrm{yr}^{-1}$ (compared to $12 \mathrm{Gg} \mathrm{yr}^{-1}$ from fertilizer application), with cropland emissions comprising 30$60 \%$ of the total. 


\section{ANNUAL NH$_{3}$ EMISSION INVENTORY}

\section{Statewide Emissions}

The $\mathrm{NH}_{3}$ emission inventory is tabulated in Appendix C. Figures 3 and 4 illustrate the distribution of statewide emissions by source category when the inventory excludes (Figure3) and includes (Figure 4) emissions from soils. We present results in this manner given the large uncertainty in the soil emissions.

Excluding soil emissions, statewide ammonia emissions for Wyoming are estimated to be $2.98 \times 10^{7} \mathrm{~kg} \mathrm{NH}_{3} \mathrm{yr}^{-1}$ (Appendix C). This estimate is only slightly larger than that obtained using the default emission factors and activities in the CMU Model, $2.81 \times 10^{7} \mathrm{~kg} \mathrm{NH}_{3} \mathrm{year}^{-1}$. Emissions from livestock, fertilizer, and wild animals dominate the inventory (Figure 3). Beef cows, heifers and steers contribute $25 \%, 13 \%$ and $12 \%$ of these emissions statewide. Fertilizer application is $21 \%$ of the statewide total, and a single fertilizer, anhydrous ammonia, represents almost half of all fertilizer emissions. Aside from cattle and fertilizers, only seven other sources contribute more than $1 \%$ to the total ammonia emission inventory: deer (8.4\%), elk (5.4\%), antelope (4.1\%), wildfire (2.1\%), sheep (1.9\%), horses (1.6\%), and hogs and pigs (1.5\%).

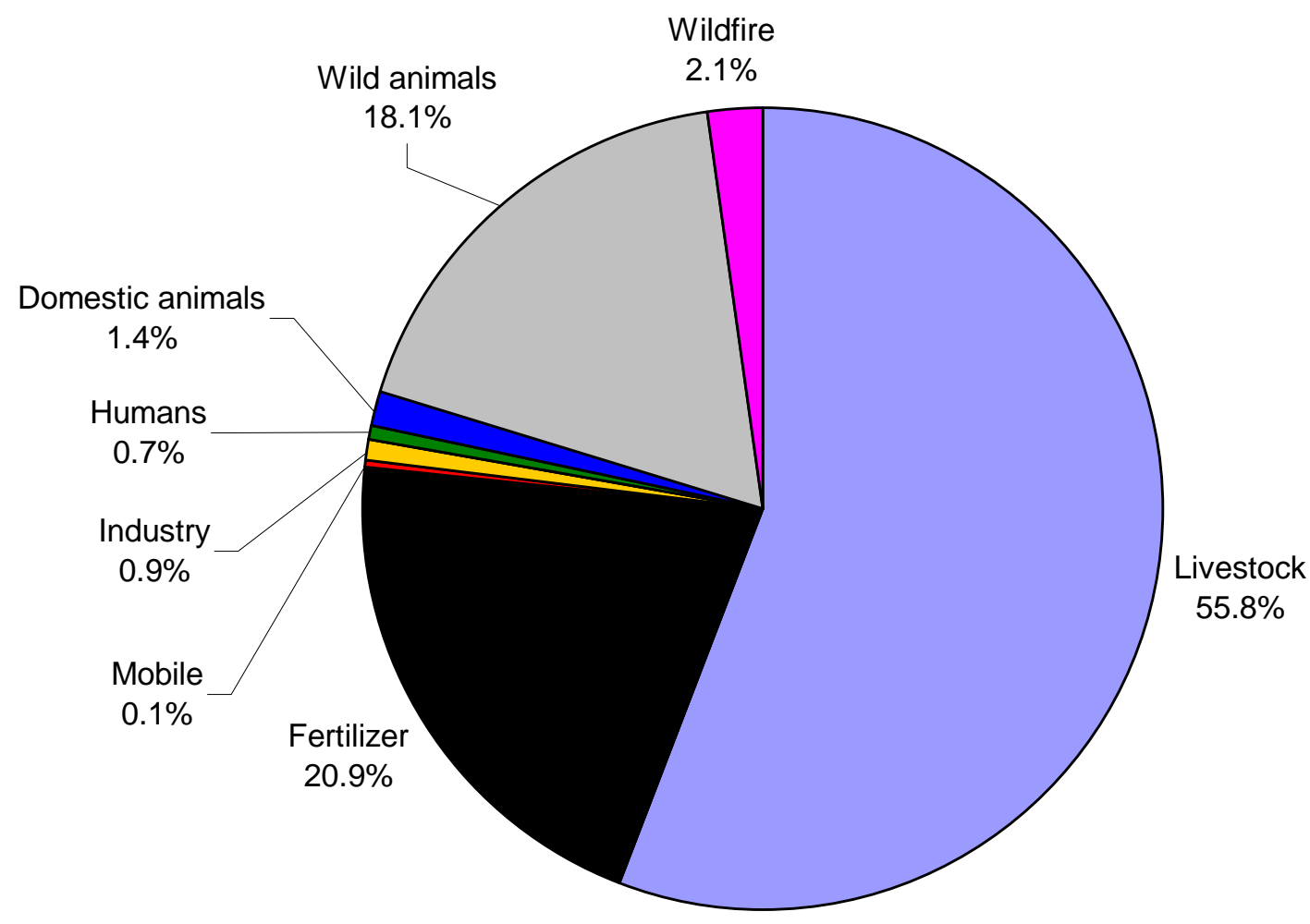

Figure 3. Contributions from different source categories (excluding soils) to the statewide $\mathrm{NH}_{3}$ emission inventory in Wyoming derived using the CMU Model calculated with the emission factors and activity data tabulated in Appendices A and B. 
Inclusion of soil results in a $300 \%$ increase in statewide emissions to $1.22 \times 10^{8} \mathrm{~kg} \mathrm{NH}$ $\mathrm{yr}^{-1}$. In this case (Figure 4), soil emissions represent three-quarters of the total $\mathrm{NH}_{3}$ inventory. Emissions from agricultural land, rangeland, and forest comprise all of the $\mathrm{NH}_{3}$ emissions from soils. Specifically, five soil subcategories contribute substantially to the statewide inventory: shrub/brush rangeland (27\%), mixed range land (18\%), herbaceous rangeland (10\%), cropland/pasture agricultural land (15\%), and evergreen forests (5\%). Next to soil emissions, livestock, fertilizer and wild animal waste constitute most of the remaining inventory, as shown in Figure 4.

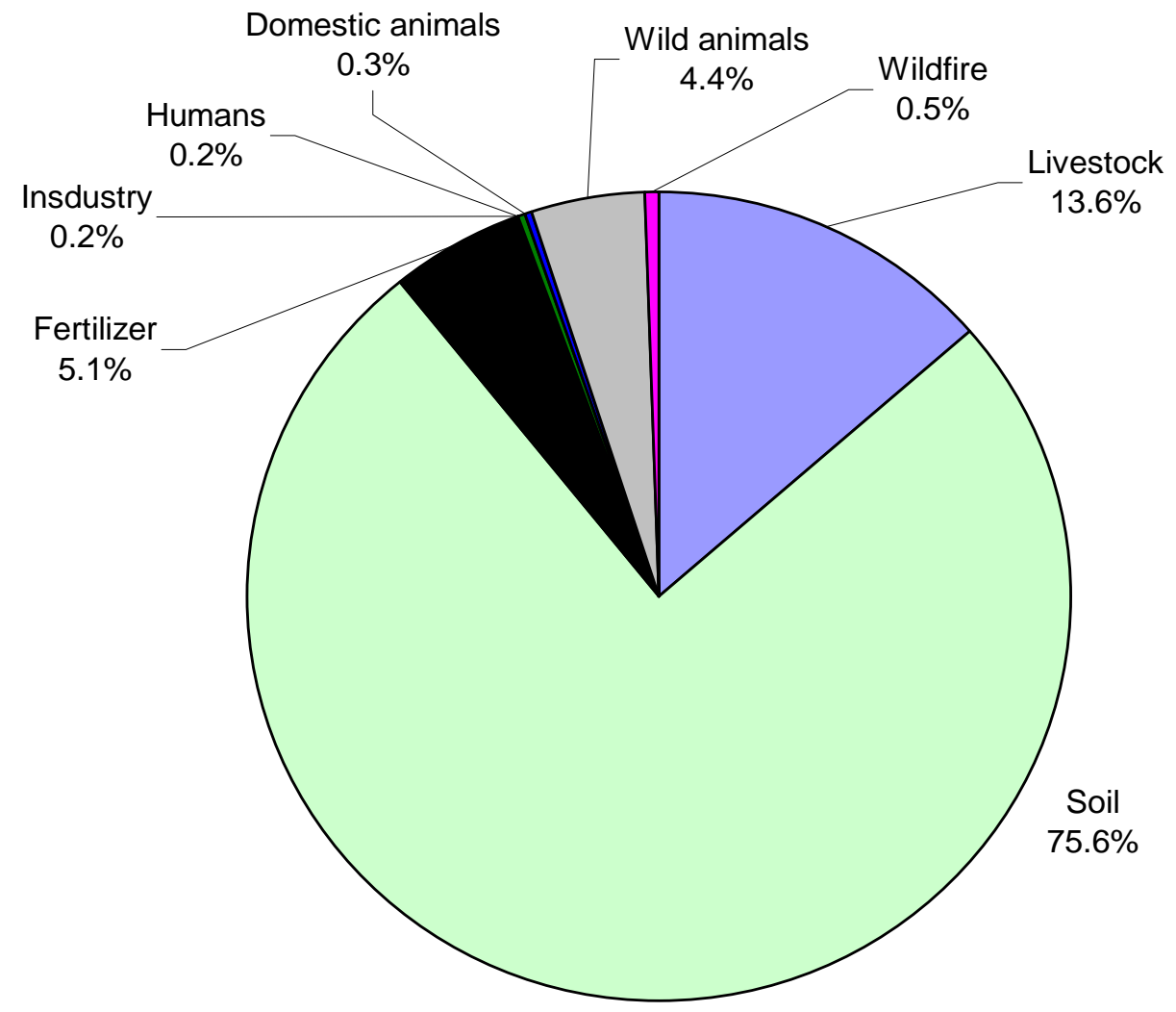

Figure 4. Contributions from different source categories (including soils) to the statewide $\mathrm{NH}_{3}$ emission inventory in Wyoming derived using the CMU Model calculated with the emission factors and activity data tabulated in Appendices A and B.

\section{County Level Emissions}

Figure 5 shows the magnitude of $\mathrm{NH}_{3}$ emissions from the different source categories at the county level. Similar to the state level, biogenic emission from soil is the largest source of $\mathrm{NH}_{3}$ in all counties in Wyoming. Barring soil, emissions from livestock represent more than half of the inventory in most counties. Exceptions include Big Horn, Laramie, Sweetwater, and Washakie, where emissions from fertilizer are a major contribution to the county inventory; 
Teton, where wildlife emissions are more dominant than those from livestock; and Park, where fertilizer and wildlife emissions together result in more $\mathrm{NH}_{3}$ emissions than livestock. The contributions of the different source categories to county emission inventories, excluding soil, are reported in Table 7.

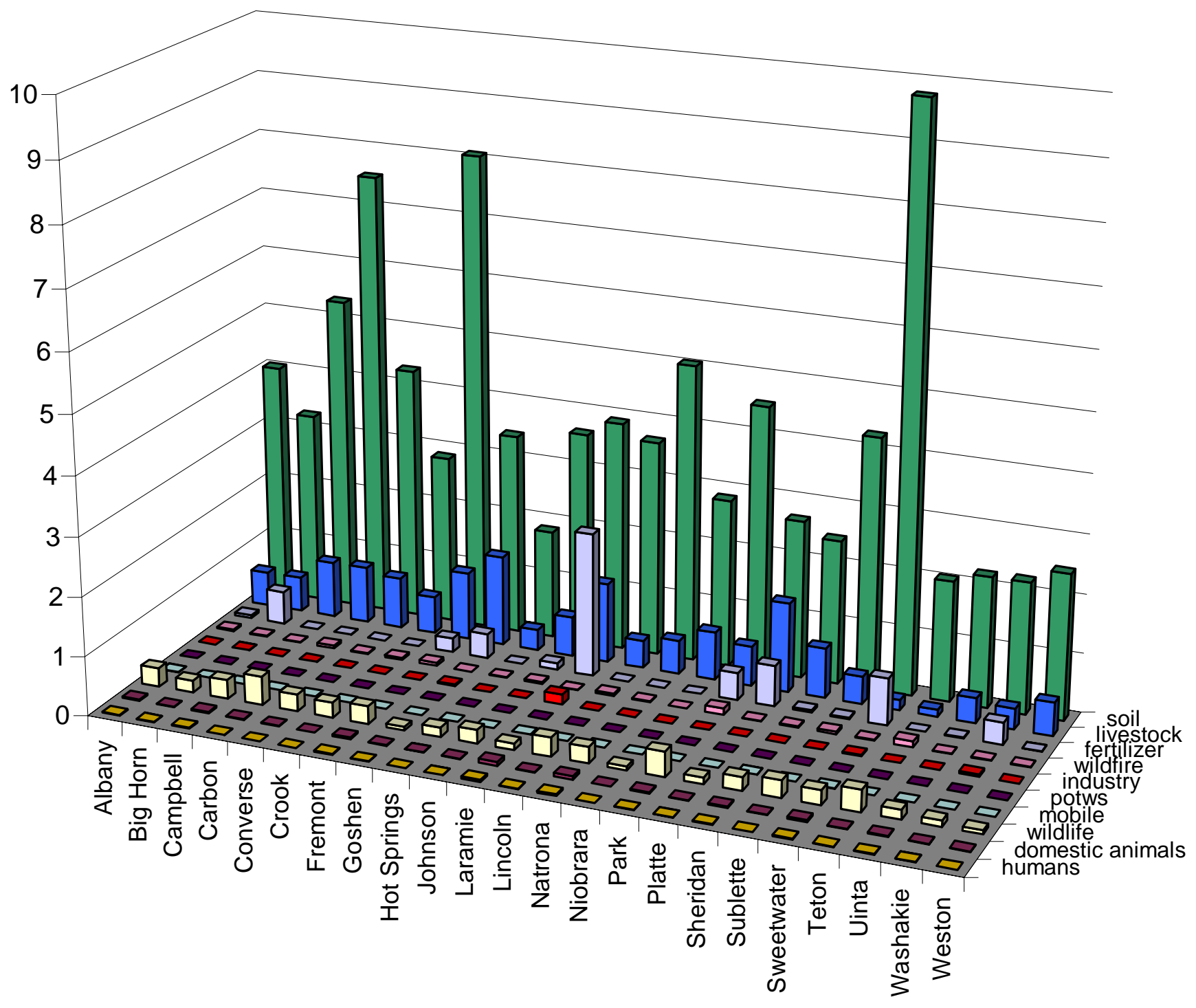

Figure 5. Estimated ammonia emissions $\left(\mathrm{Gg} \mathrm{yr}^{-1}\right)$ from Wyoming Counties by source category.

Figure 5 and Table 7 indicate that emissions vary greatly within Wyoming. Most notably, fertilizer emissions are large $(>0.2 \mathrm{Gg})$ in eight counties and small $(<0.01 \mathrm{Gg})$ in ten counties. Fertilizer emissions in Laramie County are $40 \%$ of the total fertilizer emissions in the state. Wildfire emissions of $\mathrm{NH}_{3}$ are also highly skewed; emissions from Park and Teton 
Counties equal $34 \%$ of the states total $\mathrm{NH}_{3}$ emissions from wildfires. Ammonia emissions from humans, domestic animals, industry, mobile sources, and publicly owned treatment works are minor. Even when excluding soil emissions, these source categories combined equal 5\% or less of $\mathrm{NH}_{3}$ emissions in all but three Wyoming counties.

Table 7. Source category contributions (rounded to nearest \%) to county $\mathrm{NH}_{3}$ emissions, soil emissions excluded.

\begin{tabular}{lrrrrrrrrr}
\hline & livestock & fertilizer & wildlife & wildfire & dom animal & humans & industry & mobile & POTWs \\
\hline Albany & 57 & 5 & 31 & 3 & 3 & 1 & 0 & 0 & 0 \\
Big Horn & 42 & 40 & 15 & 1 & 1 & 0 & 0 & 0 & 0 \\
Campbell & 72 & 0 & 24 & 1 & 2 & 1 & 0 & 0 & 0 \\
Carbon & 63 & 0 & 32 & 3 & 1 & 0 & 0 & 0 & 0 \\
Converse & 73 & 0 & 24 & 1 & 1 & 0 & 0 & 0 & 0 \\
Crook & 68 & 0 & 27 & 4 & 1 & 0 & 0 & 0 & 0 \\
Fremont & 64 & 13 & 17 & 3 & 2 & 1 & 0 & 0 & 0 \\
Goshen & 75 & 20 & 3 & 0 & 1 & 0 & 1 & 0 & 0 \\
Hot Springs & 67 & 0 & 30 & 2 & 1 & 0 & 0 & 0 & 0 \\
Johnson & 64 & 11 & 22 & 3 & 1 & 0 & 0 & 0 & 0 \\
Laramie & 32 & 58 & 3 & 0 & 2 & 1 & 4 & 0 & 0 \\
Lincoln & 55 & 0 & 38 & 5 & 1 & 1 & 0 & 0 & 0 \\
Natrona & 60 & 0 & 29 & 1 & 6 & 3 & 0 & 0 & 0 \\
Niobrara & 92 & 0 & 7 & 0 & 0 & 0 & 0 & 0 & 0 \\
Park & 40 & 27 & 25 & 7 & 1 & 1 & 0 & 0 & 0 \\
Platte & 65 & 30 & 5 & 0 & 0 & 0 & 0 & 0 & 0 \\
Sheridan & 72 & 3 & 20 & 2 & 2 & 1 & 0 & 0 & 0 \\
Sublette & 56 & 3 & 35 & 5 & 1 & 0 & 0 & 0 & 0 \\
Sweetwater & 13 & 61 & 19 & 1 & 3 & 1 & 2 & 0 & 0 \\
Teton & 19 & 0 & 61 & 16 & 2 & 1 & 0 & 0 & 0 \\
Uinta & 67 & 2 & 25 & 1 & 3 & 1 & 0 & 0 & 0 \\
Washakie & 40 & 42 & 12 & 1 & 1 & 0 & 4 & 0 & 0 \\
Weston & 87 & 0 & 10 & 2 & 1 & 0 & 0 & 0 & 0 \\
\hline
\end{tabular}




\section{TEMPORAL RESOLUTION}

The lack of temporal resolution in $\mathrm{NH}_{3}$ emissions represents an unknown uncertainty in air quality modeling. Assuming annual emissions are uniform in time may lead to errors in predicted $\mathrm{PM}_{2.5}$ concentrations. Potter et al. (2001) found that the seasonal pattern in predicted soil $\mathrm{NH}_{3}$ emission was reasonably consistent with observed seasonality in $\mathrm{PM}_{2.5}$ levels in the San Joaquin Valley in California. Seasonality in $\mathrm{NH}_{3}$ emissions is expected given that fertilizer application occurs more heavily during specific seasons (Goebes et al., 2003), emission from soils is strongly related to soil temperature and moisture (Potter et al., 2001; Roelle and Aneja, 2002), and emission of $\mathrm{NH}_{3}$ from animal waste is affected by temperature (Dewes, 1996).

As discussed above, Goebes et al. (2003) developed an $\mathrm{NH}_{3}$ emission inventory for Wyoming based on fertilizer sales to farmers by county. Their inventory illustrates that the seasonality in fertilizer emissions depends on the times of planting and harvesting crops. We report the monthly fraction of yearly amount of fertilizer that is applied in each Wyoming county in Appendix D. These values were computed from the activity data in the CMU Model, which are those of Goebes et al. Figure 6 shows the percentage of total fertilizer amount applied statewide during each month of the year. Fertilizer application peaks in the spring (March and April) and fall (September) and is greater in the summer than in the winter. Thus, monthly emissions associated with each fertilizer in each county can be computed by multiplying the monthly allocation factors reported in Appendix D by the annual emissions of each fertilizer in each county listed Appendix C.

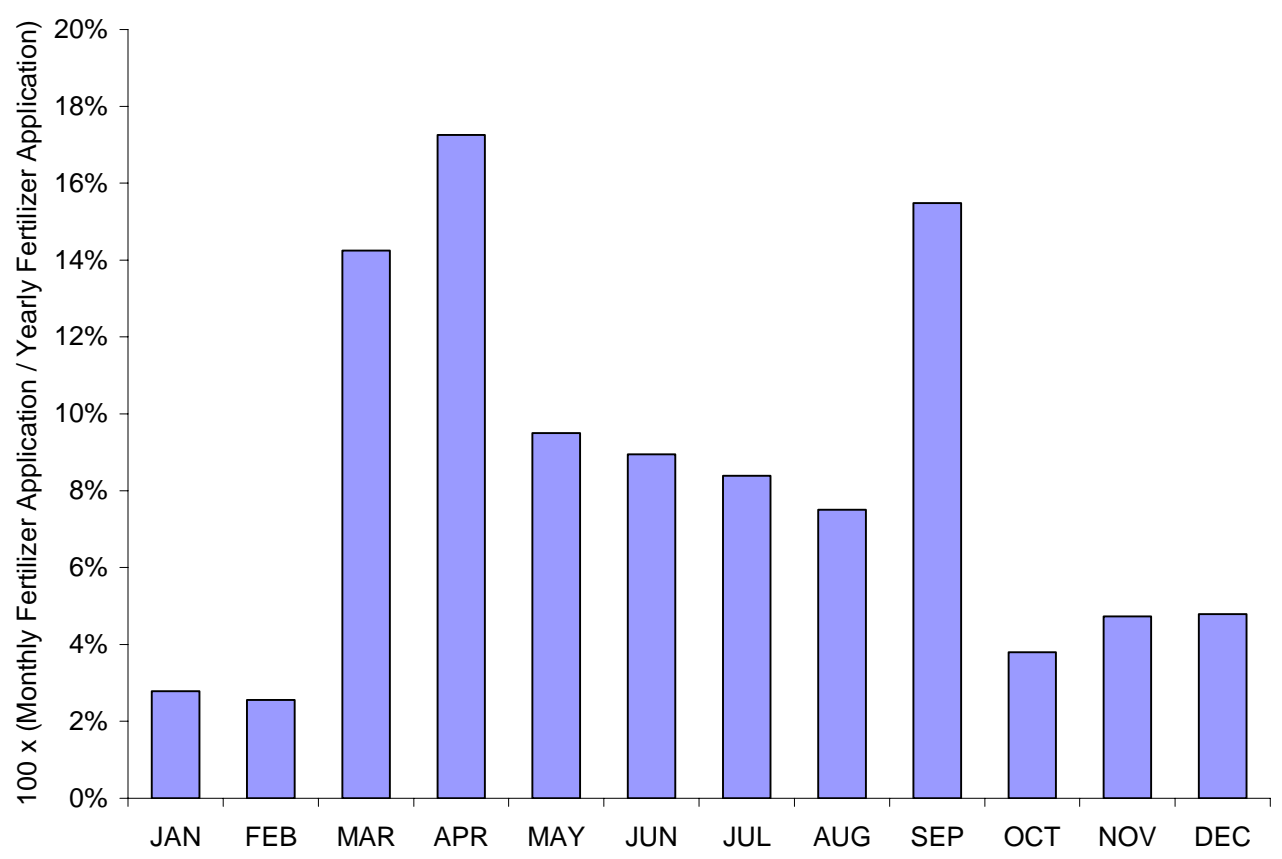

Figure 6. Yearly distribution of application of all fertilizers in Wyoming. 
Whereas the seasonality in fertilizer emissions can be approximated using information about fertilizer sales and crop schedules, data on the temporal trend in emissions from other major ammonia sources are very scarce. Perhaps the only comprehensive assessment of the seasonality in regional $\mathrm{NH}_{3}$ emissions is the recent study of Gilliland et al. (2003). Gilliland et al. found strong seasonal differences in $\mathrm{NH}_{3}$ emissions in the eastern United States using an inverse modeling technique, measured atmospheric concentrations of ammonium ion, and emission fields acquired from the EPA's national $\mathrm{NH}_{3}$ emission estimates (EPA, 2000). Gilliland et al. (2003) presented results in the form of scaling factors to be applied to the annual emission estimates to match the seasonal trend in emissions predicted with their model. These scaling factors, which are shown in Figure 7, were reported for eight months. We extrapolated these factors to estimate scaling factors for February, September, November, and December, and then normalized the scaling factors. The normalized scaling factors, also shown in Figure 7, exhibit the same trend as the original scaling factors. When the normalized scaling factors are applied to an annual emission estimate, the sum of the resulting monthly emission estimates equals $100 \%$ of the annual estimate.

Chinkin et al. (2003) also recommend using the scaling factors of Gilliland et al. (2003) to estimate the temporal variation in $\mathrm{NH}_{3}$ emissions. As shown in Figure 7 , the trend in the monthly allocation factors derived by Chinkin et al. differs from that of Gilliland et al. Chinkin et al. recommended the use of their monthly allocation factors to estimate the temporal variation in livestock emissions only, presumably because the modeling study of Gilliland et al. is based on the emission estimates of the EPA's national inventory, in which the largest sources are livestock (76\% of total emissions) and fertilizer application (10\% of total emissions).

We note that national $\mathrm{NH}_{3}$ emission estimates of the CMU Model indicate a much different composition due to significant soil emissions, which are not explicitly included in the EPA inventory: 55\% soil, 25\% livestock, and 11\% fertilizer application. Emissions from soil, while highly uncertain, may be the dominant contribution to the inventory of $\mathrm{NH}_{3}$ emissions in Wyoming (Figure 4). For soil, Chinkin et al. recommend use of seasonal profiles developed by Corsi et al. (2002), who measured emissions from pine and oak forests in Texas during the summer. Given that all the forests in Wyoming comprise 20\% of the land area (Table 6), the seasonal profile of Corsi et al. may not be applicable to all soils in Wyoming. Using an ecosystem model for soil nitrogen gas emissions, Potter et al. (2001) noted that emissions of soil $\mathrm{NH}_{3}$ are influenced by air temperature and moisture patterns; peak emissions occurred when soils were predicted to be warm and dry. Similarly, Roelle and Aneja (2002) found that emission from soils in North Carolina was influenced mainly by soil temperature, though it was also noted that soil $\mathrm{pH}$, another controlling variable, remained relatively constant during their research, and that soil moisture also affected emissions. 


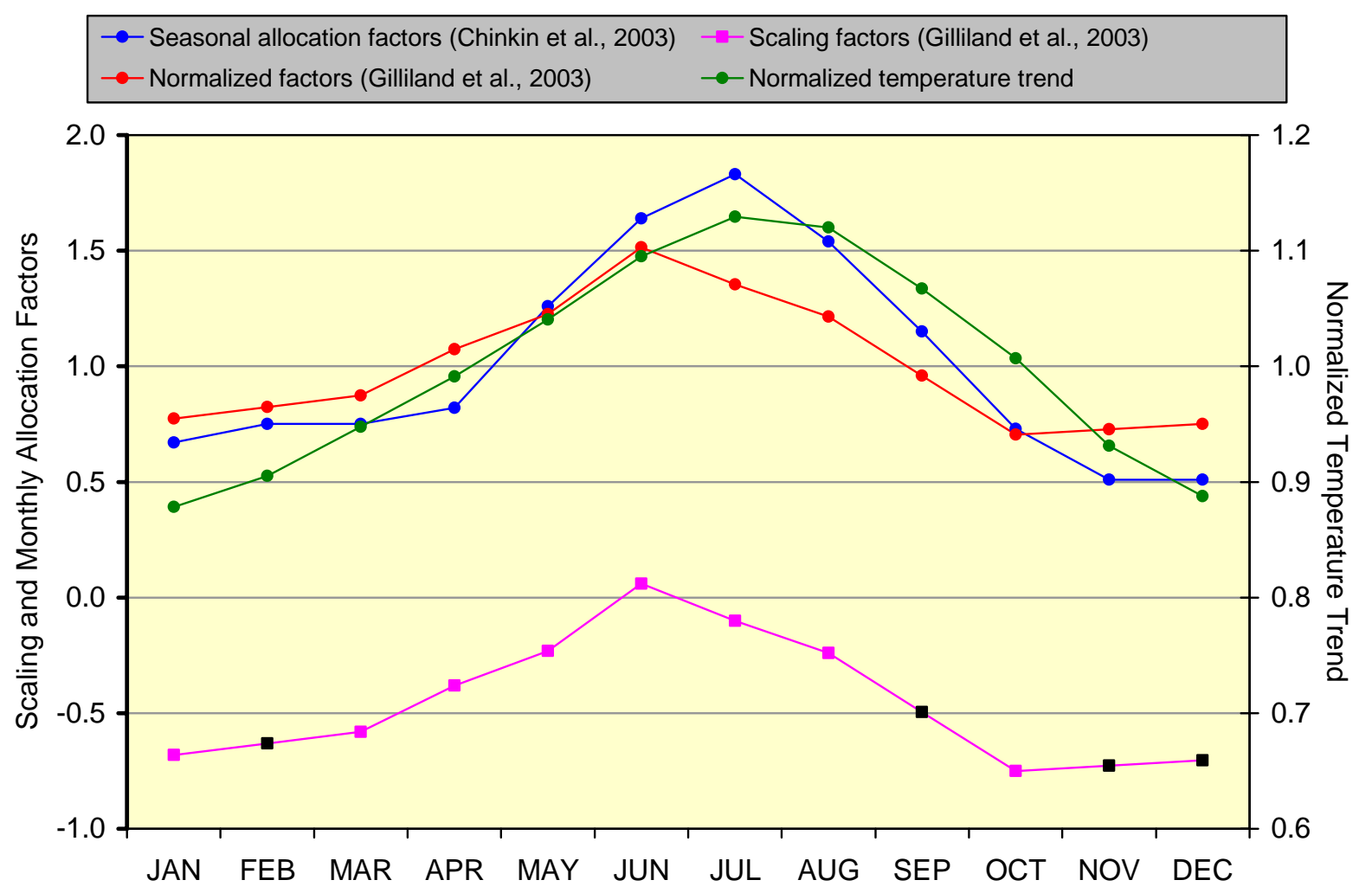

Figure 7. Seasonal scaling factors for $\mathrm{NH}_{3}$ emissions and normalized temperature trend.

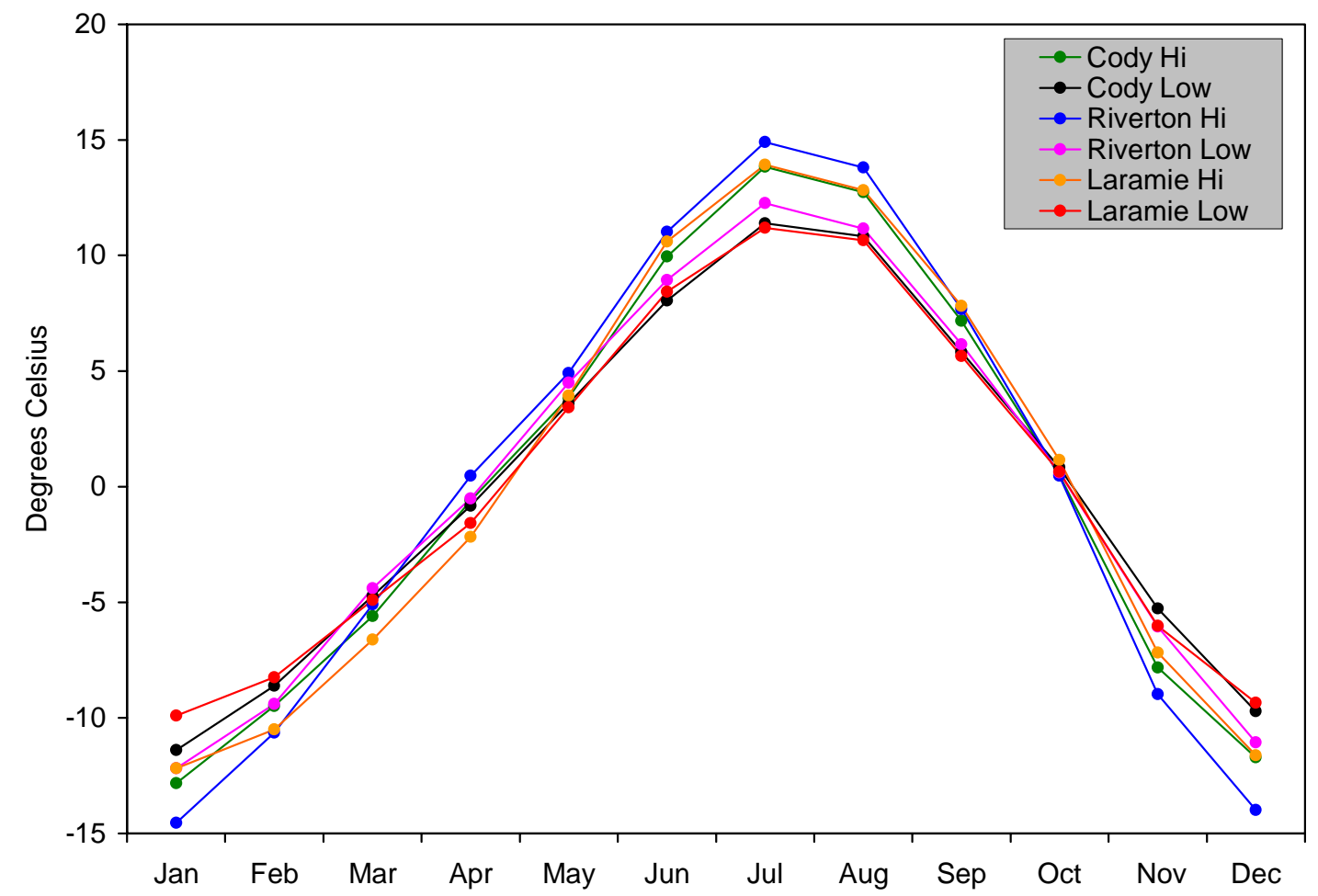

Figure 8. Differences between monthly average maximum (hi) and minimum (low) temperatures and annual average temperature in three Wyoming cities. 
Since temperature influences $\mathrm{NH}_{3}$ emissions from soil and animal waste, we considered the temporal variability in temperature measured at several locations across Wyoming (www.weather.com; >30 yr record). We found that while absolute temperatures vary between locations, differences between monthly and annual average temperatures exhibit similar trends at each location, as illustrated in Figure 8. The average temperature trend was normalized and included in Figure 7 for comparison with the above-mentioned monthly allocation factors. The qualitative features of the temperature and allocation trends generally agree: peak temperatures and peak $\mathrm{NH}_{3}$ emissions occur during the summer months. This is by no means sufficient evidence to validate use of these monthly scaling factors for Wyoming. Rather, the temperature trend illustrates that temporal variation in emissions is probable.

Given the evidence for temporal $\mathrm{NH}_{3}$ emissions and the importance of including realistic emission profiles in air quality models, and because seasonality data specific to Wyoming do not presently exist, we applied the normalized scaling factors of Gilliland et al. (2003) to the annual emission estimates (Appendix D) to estimate monthly $\mathrm{NH}_{3}$ emissions from livestock, wild animals, and soil. We note, however, that the profile developed by Gilliland et al. applies to the eastern United States (nominally for livestock only), and the appropriate profile for Wyoming needs to be determined. The profile data illustrated in Figure 7 are reported in Table 8.

Table 8. Monthly allocation factors derived from Gilliland et al. (2003).

\begin{tabular}{cccc}
\hline Month & Factor & Month & Factor \\
\hline Jan & 0.77 & Jul & 1.35 \\
Feb & 0.82 & Aug & 1.21 \\
Mar & 0.87 & Sep & 0.96 \\
Apr & 1.07 & Oct & 0.70 \\
May & 1.22 & Nov & 0.73 \\
Jun & 1.51 & Dec & 0.75 \\
\hline
\end{tabular}

Application of the monthly allocation factors in Table 8 to soil, livestock, and wild animal emissions, and in Appendix $\mathrm{C}$ to fertilizer activity, yields the temporal trend in statewide emissions shown in Figure 9. Estimated $\mathrm{NH}_{3}$ emissions peak in June and are greater in the late spring and early summer than in the fall and winter. When soil emissions are not included in the inventory, emissions are more evenly distributed throughout the spring and summer seasons, in addition to being considerably smaller in magnitude, as shown in Figure 10. 


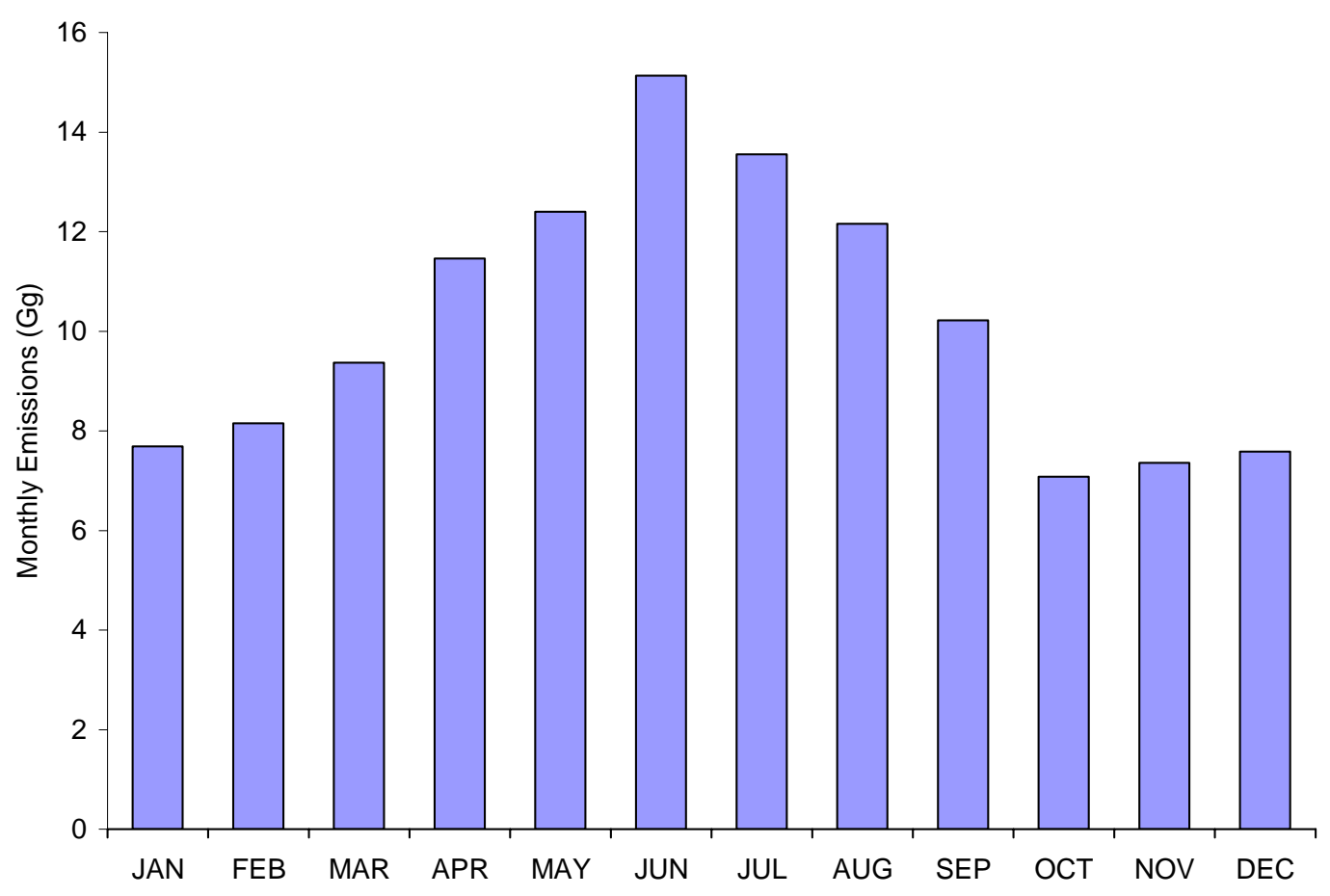

Figure 9. Monthly emissions of $\mathrm{NH}_{3}$ in Wyoming assuming temporally dependent fertilizer application and soil, livestock, and wild animal emissions, as discussed in the text.

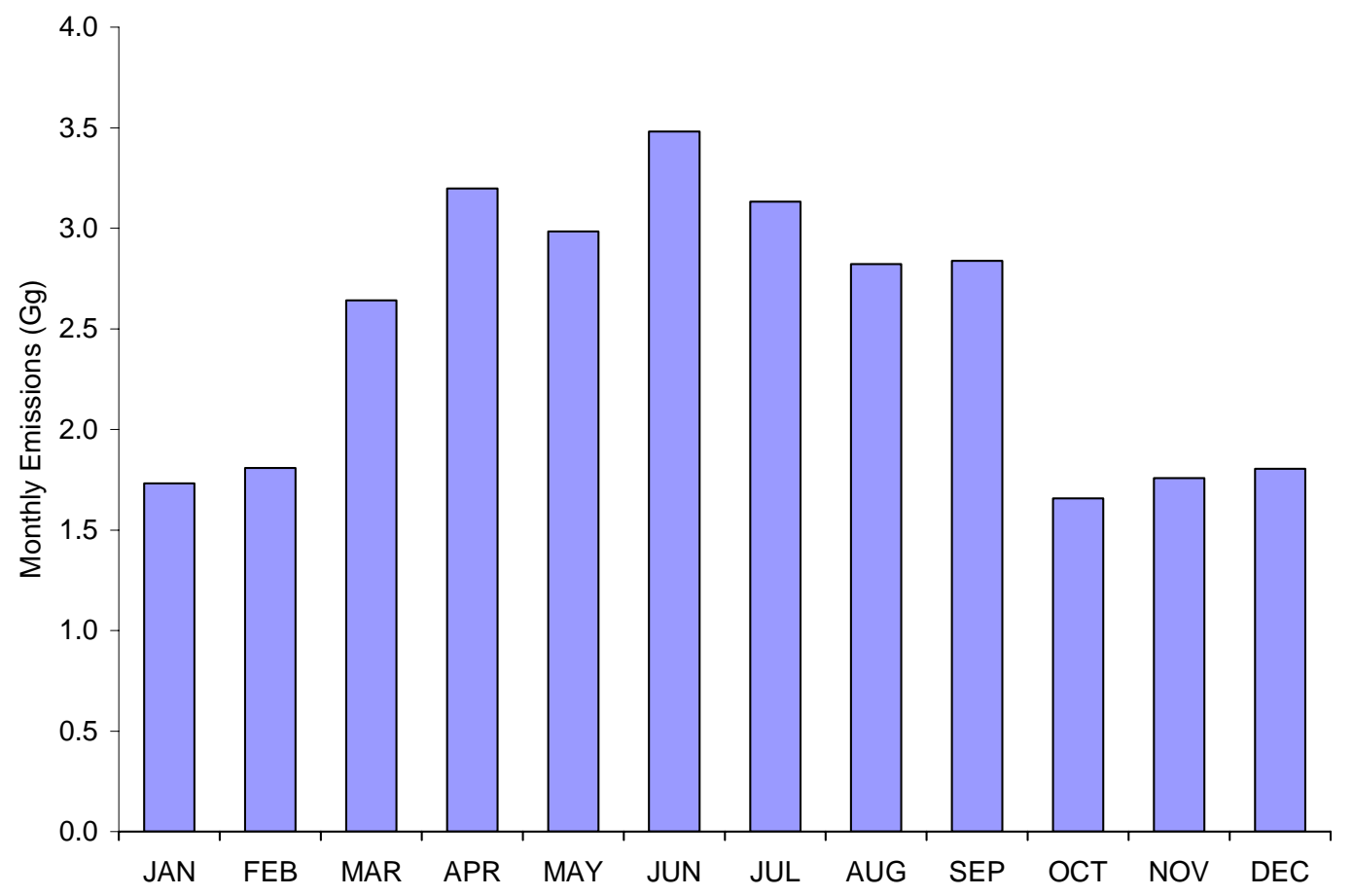

Figure 10. Monthly emissions of $\mathrm{NH}_{3}$ in Wyoming assuming temporally dependent fertilizer application and livestock and wild animal emissions (soil emissions excluded), as discussed in the text. 


\section{CONCLUSION}

An $\mathrm{NH}_{3}$ emission inventory was developed for the state of Wyoming using the CMU Ammonia Model, which can be used to estimate $\mathrm{NH}_{3}$ emissions nationwide. Default emission factors and, in particular, activity levels were updated for specific application of the CMU Model to Wyoming. The emission inventory is spatially and temporally resolved to the county and monthly level.

The largest portion of the $\mathrm{NH}_{3}$ inventory is biogenic emission from soils, for which emission factors are highly uncertain. Published emission factors are scarce and based on limited measurements. In Wyoming, agricultural land, rangeland, and forests comprise 96\% of the land area and essentially all of the estimated emissions from soils. Thus, future research on emission rates of $\mathrm{NH}_{3}$ for these land categories may lead to a substantial change in the magnitude of soil emissions, a different inventory composition, and reduced uncertainty in the inventory.

While many $\mathrm{NH}_{3}$ inventories include annual emissions, air quality modeling studies require finer temporal resolution. Published studies indicate higher emission rates from soils and animal wastes at higher temperatures, and temporal variation in fertilizer application. A recent inverse modeling study indicates temporal variation in regional $\mathrm{NH}_{3}$ emissions. In this study, derived monthly allocation factors were applied to annual emission estimates to calculate monthly emissions from soil, livestock and wild animal waste. Monthly resolution of $\mathrm{NH}_{3}$ emissions from fertilizers is incorporated into the CMU Model, and is based on fertilizer sales to farmers. Results from this study indicate that statewide $\mathrm{NH}_{3}$ emissions are largest in the late spring and early summer months. 


\section{REFERENCES}

AAPFCO, Association of American Plant Food Control Officials, 1995. Commercial Fertilizers 1995.

Ament W., Huizenga, J.R., Mook, G.A., Gips, C.H., Verkerke, G.J. Lactate and ammonia concentration in blood and sweat during incremental cycle ergometer exercise, International Journal of Sports Medicine, 18, 35-39, 1997.

American Veterinary Medical Association, U.S. pet Ownership \& Demographics Sourcebook, 1997.

Anderson, J.R., Hardy, E.E., Roach, J.T., Witmer, R.E., 1976. A Land Use and Land Cover Classification System for Use with Remote Sensor Data: U.S. Geological Survey Professional Paper PP-964, U.S. Geological Survey, Reston, Virginia.

Asman W.A.H., 1992. Ammonia Emissions for Europe. Report no. 228471008 for National Institute of Public Health and Environmental Protection, Bilthoven.

Battye, R., Battye, W., Overcash, C., and Fudge, S., 1994. Development and selection of ammonia emission factors. Prepared by EC/R, Inc for the US-EPA Atmospheric Research and Exposure Assessment Laboratory, EPA Contract No. 68-D3-0034.

Benjamin, M., 2003. California Air Resources Board, Personal communication. Draft Ammonia Inventory Developed by the California Air Resources Board, as of May 11, 2001.

Berckefeldt, Lynda, 2003. Wyoming State Forestry Division, Personal communication.

Bouwman, A.F. and Van Der Hoek, K.W. Scenarios of animal waste production and fertilizer use and associated ammonia emission for the developing countries, Atmospheric Environment, 31, 4095-4102, 1997.

Bouwman, A.F., D.S. Lee, W.A.H., Asman, Dentener, F.J., Van Der Hoek, K.W. and Olivier, J.G.J. A global high-resolution emission inventory for ammonia, Global Biogeochemical Cycles, 11, 561-587, 1997.

Chinkin, L.R., Ryan, P.A., Coe. D.L. Recommended Improvements to the CMU Ammonia Emission Inventory Model for Use by LDCO for Lake Michigan Air Directors Consortium by Sonoma Technology, Inc. 902350-2249-FR2, 2003.

CMU, Carnegie Mellon University Ammonia Model, V3.0 PUBLIC BETA, released in April 2003, downloaded from www.cmu.edu/ammonia, 2003.

Coe, D.L., Chinkin, L.R., Loomis C., Wilkinson, J., Zwicker, J., Fitz, D., Pankratz, D., and Ringler, E. (1998) Technical Support Study 15: Evaluation and improvement of methods for determining ammonia emissions in the San Joaquin Valley. Report prepared for the 
California Air Resources Board, Sacramento, CA by Sonoma Technology, Inc., Santa Rosa, CA, STI95310-1759-FR.

Dentener, F.J.; Crutzen, P.J. A three-dimensional model of the global ammonia cycle, J. Atmos. Chem., 19, 331-369, 1994.

Dewes, T. Effect of $\mathrm{pH}$, temperature, amount of litter and storage density on ammonia emissions from stable manure, J. Agricultural Sci., 127, 501-509, 1996.

Durbin, T.D., Wilson, R.D., Norbeck, J.M., Miller, J.W., Huai, T., and Rhee, S.H. Estimates of the emission rates of ammonia from light-duty vehicles using standard chassis dynamometer test cycles, Atmospheric Environment, 36, 1475-1482, 2002.

EarthTech, Inc. and Air Sciences, Inc. (1998) 1995 Air Emissions Within the Southwest Wyoming Regional Modeling Domain, Vols 1-3, Draft Final Report. December 1998.

EPA, Environmental Protection Agency's (EPA) Office of Information Resources Management (OIRM), 1994, GIRAS Landuse/Landcover data for the Conterminous United States by quadrangles at scale 1:250,000.

EPA, Environmental Protection Agency, 1996. “Clean water needs survey: Population served, report \#2”, Office of Wastewaater Management, online report accessed fall 2003, http://www.epa.gov/owm/mtb/cwns/1996report2/index.htm.

EPA, Environmental Protection Agency, 2000. National Air Pollutant Emission Trends: 19001998, EPA 454/R-00-002. www.epa.gov/ttn/chief/trends/trends98

EPA, Environmental Protection Agency, 2002. Toxic Release Inventory. http://www.epa.gov/tri/ accessed July 2003.

European Environmental Agency, 2001. Joint EMEP/CORINAIR Atmospheric Emission Inventory Guidebook, third Edition. Copenhagen: European Environmental Agency.

Fraser, M.P. and G.R. Cass. Detection of excess ammonia emissions from in-use vehicles and the implications for fine particle control, Environmental Science and Technology, 32, 1053-1057, 1998.

Gilliland, A.B.; Dennis, R.L.; Roselle, S.J.; Pierce, T.E. Seasonal $\mathrm{NH}_{3}$ emission estimates for the eastern United States based on ammonia wet concentration and an inverse modeling method, J. Geophys. Res, 108, doi:10.1029/2002JD003063, 2003.

Goebes, M.D., Strader, R. and Davidson, C. An ammonia emission inventory for fertilizer application in the United States, Atmospheric Environment, 37, 2539-2550, 2003.

Goode, J.G., Yokelson, R.J., Ward, D.E., Susott, R.A.,Babbitt, R.E., Davies, M.A. and Hao, W.M. 2000. Measurements of excess $\mathrm{O}_{3}, \mathrm{CO}_{2}, \mathrm{CO}, \mathrm{CH}_{4}, \mathrm{C}_{2} \mathrm{H}_{4}, \mathrm{C}_{2} \mathrm{H}_{2}, \mathrm{HCN}, \mathrm{NO}, \mathrm{NH}_{3}$, 
$\mathrm{HCOOH}, \mathrm{CH}_{3} \mathrm{COOH}, \mathrm{HCHO}$, and $\mathrm{CH}_{3} \mathrm{OH}$ in 1997 Alaskan biomass burning plumes by airborne Fourier transform infrared spectroscopy (AFTIR), Journal of Geophysical Research, $105,22147$.

Hegg, D.A., Radke, L.F., and Hobbs, P.V., 1988. Ammonia Emissions from Biomass Burning. Geophysical Research Letters, 15, 335-337.

Kean, A.J., Harley, R.A., Littlejohn, D. and Kendall, G.R. On-road measurement of ammonia and other motor vehicle exhaust emissions, Environmental Science and Technology, 34, 3535-3539, 2000.

Lee, Y. and Park, S. Estimation of Ammonia Emission in South Korea: Water, Air, and Soil Pollution, 135: 23-37, 2002.

Roe, S. M. and Mansell, G.E. Next generation ammonia inventory for the San Joaquin Valley of California, E.H. Pechan \& Associates and Environ International Corporation, 2001.

Misselbrook, T.H., Van Der Weerden, T.J., Pain, B.F., Jarvis, S.C., Chambers, B.J., Smith, K.A., Phillips, V.R., Demmers, T.G.M., 2000. Ammonia emission factors for UK agriculture. Atmospheric Environment, 34, 871-880.

National Interagency Fire Center, 2000. www.nifc.gov.

North American Bear Center, accessed July 2003, http://www.bear.org.

Pain, B.F., Van Der Weerden, T.J., Chambers, B.J., Phillips, V.R. and Jarvis, S.C. A New Inverntory for Ammonia Emissions From U.K. Agriculture, Atmospheric Environment, 32: 309-313, 1998.

Potter, C., Krauter, C., Klooster, S., 2001. Statewide inventory estimates of ammonia emissions from native soils and chemical fertilizers in California. Report prepared for the California Air Resources Board Emissions Inventory Branch under contract no. 98-716.

Roelle, P.A., Aneja, V.P. Characterization of ammonia emissions from soils in the upper coastal plain, North Carolina, Atm. Env., 36, 1087-1097, 2002.

Silvester K.R., Bingham, S.A., Pollock, J.R.A. Cummings, J.H., Oneill, I.K. Effect Of meat and resistant starch on fecal excretion of apparent $\mathrm{N}$-nitroso compounds and ammonia from the human large bowel, Nutrition \& Cancer-An International Journal, 29, 13-23, 1997.

Sisler, J.F. and Malm, W.C. The relative importance of soluble aerosols to spatial and seasonal trends of impaired visibility in the United States. Atmospheric Environment, 28: 851-862, 1994. 
Spanel, P., Davies S., Smith D. Quantification of ammonia in human breath by the selected ion flow tube analytical method using $\mathrm{H} 3 \mathrm{O}+$ And $\mathrm{O}-2(+)$ precursor ions. Rapid Communications in Mass Spectrometry. 12, 763-766, 1998.

Strader, Ross, 2003. Personal communication, Carnegie Mellon University.

Terry, D., 2003. Personal communication, AAPFCO secretary.

The American Bear Association, accessed 7/2003 http://www.americanbear.org

U.S. Census Bureau, 2002. United States Census. http://www.census.gov accessed 6/2003

USDA, National Agricultural Statistics Service, 1997 Census of Agriculture-County Data. Table 14 Cattle and Calves (www.usda.mannlib.cornell.edu/reports/census/ac97awy.pdf), accessed 6/2003.

Van der Weerden, T.J. and Jarvis, S.C. Ammonia emission factors for nitrogen fertilizers applied to tow contrasting grassland soils. Atm. Env., 95, 205-211, 1997.

Warn, T.E, Zemlmanowitz, S. and Saeger, M. Development and Selection of Ammonia Emission Factors for Office of Research and Development U.S. Environmental Protection Agency, Washington, D.C. by Alliance, EPA-600/7-90-014, June. EPA Contract No. 68-02-4373, Work Assignment No. 43.

Weather Channel, average city temperature for Wyoming, www.weather.com, accessed 8/2003.

Whitehead, D.C. and Raistrick, N. Ammonia volatilization from five nitrogen compounds used as fertilizers following surface application to soils. J. Soil Sci., 41, 387-394, 1009.

WRAP, Development of the 1996 base year emission inventory for regional hase analysis. Prepared by Pacific Environmental Services, Inc. and Eastern Research Group, 2001.

Wyoming Agriculture Statistics Service (WASS), 2002, www.nass.usda.gov/wy, accessed $7 / 2003$.

Wyoming Department of Transportation (WYDOT), 2003, Motor vehicle miles data file received via fax from Ben Adkison, 2003 (Ben.Adkison@dot.state.wy.us)

Wyoming Game and Fish (WYGF), 2003, Herd population estimate data file received via email from Justin Binfet, 2003 (Justin.Binfet@wgf.state.wy.us)

Wyoming Game and Fish (WYGF), 2003, hunt area maps, accessed July 2003 http://gf.state.wy/wildlife/application/nonres_03.asp

Wyoming Tourism, 2003, www.wyomingtourism.org, accessed August 2003.

Yokelson, Robert, Associate Professor of Chemistry, University of Montana, personal communication, 2002. 


\section{APPENDICIES}

Appendix A: Emission factors.

Appendix B: Annual activity levels by county.

Appendix C: Annual Ammonia Emissions (kg of $\mathrm{NH}_{3}$ per year per county).

Appendix D: Monthly allocation of fertilizers generated with the CMU Ammonia Model (CMU, 2003) and discussed by Goebes et al. (2003). 
Appendix A

\begin{tabular}{|c|c|c|c|}
\hline SOURCE & UNITS & VALUE & REFERENCES \\
\hline \multicolumn{4}{|l|}{ Livestock } \\
\hline Beef cows & $\mathrm{kg} \mathrm{head}^{-1} \mathrm{yr}^{-1}$ & 9.44 & Bouwman et al., 1997 \\
\hline Heifers & $\mathrm{kg} \mathrm{head}^{-1} \mathrm{yr}^{-1}$ & 9.44 & Bouwman et al., 1997 \\
\hline Steers & $\mathrm{kg} \mathrm{head}^{-1} \mathrm{yr}^{-1}$ & 9.44 & Bouwman et al., 1997 \\
\hline Milk cows & $\mathrm{kg} \mathrm{head}^{-1} \mathrm{yr}^{-1}$ & 24.8 & Bouwman et al., 1997 \\
\hline Boilers & $\mathrm{kg} \mathrm{head}^{-1} \mathrm{yr}^{-1}$ & 0.242 & Bouwman et al., 1997 \\
\hline Layers & $\mathrm{kg} \mathrm{head}^{-1} \mathrm{yr}^{-1}$ & 0.242 & Bouwman et al., 1997 \\
\hline Pullets 13 to 20 weeks & $\mathrm{kg} \mathrm{head}^{-1} \mathrm{yr}^{-1}$ & 0.242 & Bouwman et al., 1997 \\
\hline Pullets younger than 13 weeks & $\mathrm{kg} \mathrm{head}^{-1} \mathrm{yr}^{-1}$ & 0.242 & Bouwman et al., 1997 \\
\hline Hogs and pigs & $\mathrm{kg} \mathrm{head}^{-1} \mathrm{yr}^{-1}$ & 4.84 & Bouwman et al., 1997 \\
\hline Horses & $\mathrm{kg} \mathrm{head}^{-1} \mathrm{yr}^{-1}$ & 9.20 & Bouwman et al., 1997 \\
\hline Milk goats & $\mathrm{kg} \mathrm{head}^{-1} \mathrm{yr}^{-1}$ & 0.701 & Bouwman et al., 1997 \\
\hline Sheep & $\mathrm{kg} \mathrm{head}^{-1} \mathrm{yr}^{-1}$ & 0.774 & Bouwman et al., 1997 \\
\hline \multicolumn{4}{|l|}{ Fertilizer } \\
\hline Ammonium Nitrate & $\% \mathrm{~N}$ volatilized as $\mathrm{NH}_{3}$ & 1.0 & CMU, 2003; Goebes et al., 2003 \\
\hline Ammonium Sulfate & $\% \mathrm{~N}$ volatilized as $\mathrm{NH}_{3}$ & 5.0 & CMU, 2003; Goebes et al., 2003 \\
\hline Ammonium Thiosulfate & $\% \mathrm{~N}$ volatilized as $\mathrm{NH}_{3}$ & 2.5 & CMU, 2003; Goebes et al., 2003 \\
\hline Anhydrous Ammonia & $\% \mathrm{~N}$ volatilized as $\mathrm{NH}_{3}$ & 4.0 & CMU, 2003; Goebes et al., 2003 \\
\hline Aqueous Ammonia & $\% \mathrm{~N}$ volatilized as $\mathrm{NH}_{3}$ & 4.0 & CMU, 2003; Goebes et al., 2003 \\
\hline Calcium ammonium Nitrate & $\% \mathrm{~N}$ volatilized as $\mathrm{NH}_{3}$ & 1.0 & CMU, 2003; Goebes et al., 2003 \\
\hline Diammonium Phosphate & $\% \mathrm{~N}$ volatilized as $\mathrm{NH}_{3}$ & 5.0 & CMU, 2003; Goebes et al., 2003 \\
\hline Liquid Ammonium Polyphosphate & $\% \mathrm{~N}$ volatilized as $\mathrm{NH}_{3}$ & 5.0 & CMU, 2003; Goebes et al., 2003 \\
\hline Miscellaneous & $\% \mathrm{~N}$ volatilized as $\mathrm{NH}_{3}$ & 7.0 & CMU, 2003; Goebes et al., 2003 \\
\hline Mix & $\% \mathrm{~N}$ volatilized as $\mathrm{NH}_{3}$ & 7.0 & CMU, 2003; Goebes et al., 2003 \\
\hline Monoammonium Phosphate & $\% \mathrm{~N}$ volatilized as $\mathrm{NH}_{3}$ & 5.0 & CMU, 2003; Goebes et al., 2003 \\
\hline Nitrogen Solutions & $\% \mathrm{~N}$ volatilized as $\mathrm{NH}_{3}$ & 8.0 & CMU, 2003; Goebes et al., 2003 \\
\hline Potassium Nitrate & $\% \mathrm{~N}$ volatilized as $\mathrm{NH}_{3}$ & 1.0 & CMU, 2003; Goebes et al., 2003 \\
\hline Urea & $\% \mathrm{~N}$ volatilized as $\mathrm{NH}_{3}$ & 15 & CMU, 2003; Goebes et al., 2003 \\
\hline \multicolumn{4}{|l|}{ Wild Animals } \\
\hline Black bear & $\mathrm{kg} \mathrm{head}^{-1} \mathrm{yr}^{-1}$ & 66.1 & Warn et al., 1990 \\
\hline Grizzly bear & $\mathrm{kg} \mathrm{head}^{-1} \mathrm{yr}^{-1}$ & 182 & Warn et al., 1990 \\
\hline
\end{tabular}




\section{Appendix A}

\begin{tabular}{|c|c|c|c|}
\hline SOURCE & UNITS & VALUE & REFERENCES \\
\hline Deer & $\mathrm{kg} \mathrm{head}^{-1} \mathrm{yr}^{-1}$ & 4.76 & Warn et al., 1990 \\
\hline Elk & $\mathrm{kg} \mathrm{head}^{-1} \mathrm{yr}^{-1}$ & 17.2 & Warn et al., 1990 \\
\hline Antelope & $\mathrm{kg} \mathrm{head}^{-1} \mathrm{yr}^{-1}$ & 2.86 & Warn et al., 1990 \\
\hline \multicolumn{4}{|l|}{ Motor Vehicles } \\
\hline Vehicles with catalysts & $\mathrm{mg} \mathrm{mi}^{-1}$ & 80 & Bouwman et al, 1997; Fraser \& Cass, 1998; Kean et al, 2000; Durbin et al, 2002 \\
\hline Vehicles without catalysts & $\mathrm{mg} \mathrm{mi}^{-1}$ & 5 & Bouwman et al, 1997; Fraser and Cass, 1998; Durbin et al., 2002 \\
\hline \multicolumn{4}{|l|}{ Wildfires } \\
\hline Wildfire CO & $\mathrm{kg} \mathrm{CO/ton} \mathrm{wood} \mathrm{burned}$ & 90 & Goode et al., 2000 \\
\hline Wildfire ratio of $\mathrm{NH} 3$ to $\mathrm{CO}$ & mole $\mathrm{NH}_{3} /$ mole $\mathrm{CO}$ & 0.02 & Goode et al., 2000 \\
\hline \multicolumn{4}{|l|}{ POTWs } \\
\hline POTWs & 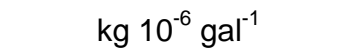 & 0.054 & CMU, 2003 \\
\hline \multicolumn{4}{|l|}{ Humans } \\
\hline Human population & $\mathrm{kg}$ person ${ }^{-1} \mathrm{yr}^{-1}$ & 0.44 & CMU, 2003 \\
\hline \multicolumn{4}{|l|}{ Domestic Animals } \\
\hline Dogs & $\mathrm{kg} \mathrm{dog}^{-1} \mathrm{yr}^{-1}$ & 2.18 & CMU, 2003 \\
\hline Cats & $\mathrm{kg} \mathrm{cat}^{-1} \mathrm{yr}^{-1}$ & 0.69 & CMU, 2003 \\
\hline \multicolumn{4}{|l|}{ Biogenic Soil } \\
\hline Unknown (0) & $\mathrm{kg} \mathrm{km}^{-2} \mathrm{yr}^{-1}$ & 30.8 & CMU, 2003 \\
\hline Urban or built upland (11-17) & $\mathrm{kg} \mathrm{km}^{-2} \mathrm{yr}^{-1}$ & 13.3 & CMU, 2003 \\
\hline Agricultural land & $\mathrm{kg} \mathrm{km}^{-2} \mathrm{yr}^{-1}$ & 0 & CMU, 2003 \\
\hline 21-Cropland and pasture & $\mathrm{kg} \mathrm{km}^{-2} \mathrm{yr}^{-1}$ & 100 & CMU, 2003 \\
\hline 22-Orchards, groves, nurseries & $\mathrm{kg} \mathrm{km}^{-2} \mathrm{yr}^{-1}$ & 108 & CMU, 2003 \\
\hline 23-Confined feeding operations & $\mathrm{kg} \mathrm{km}^{-2} \mathrm{yr}^{-1}$ & 0 & CMU, 2003 \\
\hline 24- Other agricultural land & $\mathrm{kg} \mathrm{km}^{-2} \mathrm{yr}^{-1}$ & 100 & CMU, 2003 \\
\hline Rangeland(31-33) & $\mathrm{kg} \mathrm{km}^{-2} \mathrm{yr}^{-1}$ & 30.8 & CMU, 2003 \\
\hline Forestland (41-43) & $\mathrm{kg} \mathrm{km}^{-2} \mathrm{yr}^{-1}$ & 11.7 & CMU, 2003 \\
\hline Water (51-54) & $\mathrm{kg} \mathrm{km}^{-2} \mathrm{yr}^{-1}$ & 0 & CMU, 2003 \\
\hline Wetland (61-62) & $\mathrm{kg} \mathrm{km}^{-2} \mathrm{yr}^{-1}$ & 30.8 & CMU, 2003 \\
\hline Barren land (71-77) & $\mathrm{kg} \mathrm{km}^{-2} \mathrm{yr}^{-1}$ & 0 & CMU, 2003 \\
\hline 71-Dry salt flats & $\mathrm{kg} \mathrm{km}^{-2} \mathrm{yr}^{-1}$ & 0.56 & CMU, 2003 \\
\hline 72- Beaches & $\mathrm{kg} \mathrm{km}^{-2} \mathrm{yr}^{-1}$ & 0 & CMU, 2003 \\
\hline
\end{tabular}


Appendix A

\begin{tabular}{llcl}
\hline SOURCE & UNITS & VALUE & REFERENCES \\
\hline 73- Sandy areas not beaches & $\mathrm{kg} \mathrm{km}^{-2} \mathrm{yr}^{-1}$ & 0 & CMU, 2003 \\
74- Bare exposed rock & $\mathrm{kg} \mathrm{km}^{-2} \mathrm{yr}^{-1}$ & 0 & $\mathrm{CMU}, 2003$ \\
75- Strip mines, quarries, gravel & $\mathrm{kg} \mathrm{km}^{-2} \mathrm{yr}^{-1}$ & 0 & $\mathrm{CMU}, 2003$ \\
76-Transitional areas & $\mathrm{kg} \mathrm{km}^{-2} \mathrm{yr}^{-1}$ & 30.8 & $\mathrm{CMU}, 2003$ \\
77- Mixed barren land & $\mathrm{kg} \mathrm{km}^{-2} \mathrm{yr}^{-1}$ & 5 & $\mathrm{CMU}, 2003$ \\
Tundra (81-85) & $\mathrm{kg} \mathrm{km}^{-2} \mathrm{yr}^{-1}$ & 0 & $\mathrm{CMU}, 2003$ \\
Perennial snow or ice (91-92) & $\mathrm{kg} \mathrm{km}^{-2} \mathrm{yr}^{-1}$ & 0 & CMU, 2003 \\
\hline
\end{tabular}




\section{Appendix B}

\begin{tabular}{|c|c|c|}
\hline SOURCE & UNITS & REFERENCE \\
\hline \multicolumn{3}{|l|}{ Livestock } \\
\hline Beef cows & number & USDA, 2003; WASS, 2002 \\
\hline Heifers & number & USDA, 2003; WASS, 2002 \\
\hline Steers & number & USDA, 2003; WASS, 2002 \\
\hline Milk cows & number & USDA, 2003; WASS, 2002 \\
\hline Boilers & number & CMU, 2003 \\
\hline Layers & number & CMU, 2003 \\
\hline Pullets 13 to 20 weeks & number & CMU, 2003 \\
\hline Pullets younger than 13 weeks & number & CMU, 2003 \\
\hline Hogs and pigs & number & CMU, 2003 \\
\hline Horses & number & CMU, 2003 \\
\hline Milk goats & number & CMU, 2003 \\
\hline Sheep & number & CMU, 2003 \\
\hline \multicolumn{3}{|l|}{ Fertilizer } \\
\hline Ammonium Nitrate & tons $\mathrm{yr}^{-1}$ & CMU, 2003; Goebes et al., 2003 \\
\hline Ammonium Sulfate & tons $\mathrm{yr}^{-1}$ & CMU, 2003; Goebes et al., 2003 \\
\hline Ammonium Thiosulfate & tons $\mathrm{yr}^{-1}$ & CMU, 2003; Goebes et al., 2003 \\
\hline Anhydrous Ammonia & tons $\mathrm{yr}^{-1}$ & CMU, 2003; Goebes et al., 2003 \\
\hline Aqueous Ammonia & tons $\mathrm{yr}^{-1}$ & CMU, 2003; Goebes et al., 2003 \\
\hline Calcium ammonium Nitrate & tons $\mathrm{yr}^{-1}$ & CMU, 2003; Goebes et al., 2003 \\
\hline Diammonium Phosphate & tons $\mathrm{yr}^{-1}$ & CMU, 2003; Goebes et al., 2003 \\
\hline Liquid Ammonium Polyphosphate & tons $\mathrm{yr}^{-1}$ & CMU, 2003; Goebes et al., 2003 \\
\hline Miscellaneous & tons $\mathrm{yr}^{-1}$ & CMU, 2003; Goebes et al., 2003 \\
\hline Mix & tons $\mathrm{yr}^{-1}$ & CMU, 2003; Goebes et al., 2003 \\
\hline Monoammonium Phosphate & tons $\mathrm{yr}^{-1}$ & CMU, 2003; Goebes et al., 2003 \\
\hline Nitrogen Solutions & tons $\mathrm{yr}^{-1}$ & CMU, 2003; Goebes et al., 2003 \\
\hline Potassium Nitrate & tons $\mathrm{yr}^{-1}$ & CMU, 2003; Goebes et al., 2003 \\
\hline Urea & tons $\mathrm{yr}^{-1}$ & CMU, 2003; Goebes et al., 2003 \\
\hline \multicolumn{3}{|l|}{ Wild Animals } \\
\hline Black bear & number & CMU, 2003 \\
\hline Grizzly bear & number & CMU, 2003 \\
\hline Deer & number & WYGF, 2003 \\
\hline Elk & number & WYGF, 2003 \\
\hline Antelope & number & WYGF, 2003 \\
\hline \multicolumn{3}{|l|}{ Motor Vehicles } \\
\hline Vehicles with catalysts & mi yr-1 & WYDOT, 2003 \\
\hline Vehicles without catalysts & mi yr-1 & WYDOT, 2003 \\
\hline \multicolumn{3}{|l|}{ Wildfires } \\
\hline Wildfire & tons wood burned & CMU, 2003 \\
\hline \multicolumn{3}{|l|}{ Industry } \\
\hline Industry & $\mathrm{kg} \mathrm{NH} 3 \mathrm{yr}^{-1}$ & CMU, 2003 \\
\hline
\end{tabular}




\section{Appendix B}

\begin{tabular}{lll}
\hline SOURCE & UNITS & REFERENCE \\
\hline POTWs & $10^{6} \mathrm{gal} \mathrm{day}^{-1}$ & $\mathrm{CMU}, 2003$ \\
Humans & & \\
Human population & number & US Census Bureau, 2002 \\
Domestic Animals & & \\
Dogs & number & $\mathrm{CMU}, 2003$ \\
Cats & number & $\mathrm{CMU}, 2003$ \\
Biogenic Soil & & \\
County Land Area & $\mathrm{km}^{2}$ & $\mathrm{CMU}, 2003$ \\
Unknown (0) & $\mathrm{km}^{2}$ & $\mathrm{CMU}, 2003$ \\
Urban or built upland (11-17) & $\mathrm{km}^{2}$ & $\mathrm{CMU}, 2003$ \\
Agricultural land & & \\
21-Cropland and Pasture & $\mathrm{km}^{2}$ & $\mathrm{CMU}, 2003$ \\
22-Orchards, groves, nurseries & $\mathrm{km}^{2}$ & $\mathrm{CMU}, 2003$ \\
23-Confined feeding operations & $\mathrm{km}^{2}$ & $\mathrm{CMU}, 2003$ \\
24- Other agricultural land & $\mathrm{km}^{2}$ & $\mathrm{CMU}, 2003$ \\
Rangeland(31-33) & $\mathrm{km}^{2}$ & $\mathrm{CMU}, 2003$ \\
Forestland (41-43) & $\mathrm{km}^{2}$ & $\mathrm{CMU}, 2003$ \\
Water (51-54) & $\mathrm{km}^{2}$ & $\mathrm{CMU}, 2003$ \\
Wetland (61-62) & $\mathrm{km}^{2}$ & $\mathrm{CMU}, 2003$ \\
Barren land & & \\
71-Dry salt flats & $\mathrm{km}^{2}$ & $\mathrm{CMU}, 2003$ \\
72- Beaches & $\mathrm{km}^{2}$ & $\mathrm{CMU}, 2003$ \\
73- Sandy areas not beaches & $\mathrm{km}^{2}$ & $\mathrm{CMU}, 2003$ \\
74- Bare exposed rock & $\mathrm{km}^{2}$ & $\mathrm{CMU}, 2003$ \\
75- Strip mines, quarries, gravel & $\mathrm{km}^{2}$ & $\mathrm{CMU}, 2003$ \\
76-Transitional areas & $\mathrm{km}^{2}$ & $\mathrm{CMU}, 2003$ \\
77- Mixed barren land & $\mathrm{km}^{2}$ & $\mathrm{CMU}, 2003$ \\
Tundra (81-85) & $\mathrm{km}^{2}$ & \\
Perennial snow or ice (91-92) & & \\
\hline
\end{tabular}




\section{Appendix B}

\begin{tabular}{|c|c|c|c|c|c|c|}
\hline SOURCE & ALBANY & BIG HORN & CAMPBELL & CARBON & CONVERSE & CROOK \\
\hline \multicolumn{7}{|l|}{ Livestock } \\
\hline Beef cows & 29652 & 31383 & 57433 & 54742 & 51877 & 34214 \\
\hline Heifers & 15234 & 13841 & 20247 & 23131 & 17848 & 14782 \\
\hline Steers & 14215 & 10079 & 15317 & 19050 & 14915 & 12398 \\
\hline Milk cows & 74 & 271 & 36 & 12 & 209 & 65 \\
\hline Boilers & 54 & 90 & 44 & 0 & 54 & 79 \\
\hline Layers & 384 & 439 & 643 & 202 & 415 & 394 \\
\hline Pullets 13 to 20 weeks & 206 & 67 & 88 & 206 & 49 & 28 \\
\hline Pullets younger than 13 weeks & 0 & 37 & 0 & 0 & 0 & 37 \\
\hline Hogs and pigs & 681 & 2220 & 194 & 122 & 48 & 881 \\
\hline Horses & 2020 & 2200 & 3180 & 2080 & 1400 & 2470 \\
\hline Milk goats & 18 & 61 & 99 & 18 & 24 & 18 \\
\hline Sheep & 6710 & 36400 & 59900 & 34200 & 68700 & 29100 \\
\hline \multicolumn{7}{|l|}{ Fertilizer } \\
\hline Ammonium Nitrate & 103240 & 1475400 & 0 & 68960 & 0 & 0 \\
\hline Ammonium Sulfate & 0 & 0 & 0 & 5548 & 0 & 0 \\
\hline Ammonium Thiosulfate & 0 & 4622 & 3370 & 0 & 529 & 0 \\
\hline Anhydrous Ammonia & 0 & 0 & 0 & 0 & 0 & 0 \\
\hline Aqueous Ammonia & 0 & 0 & 0 & 0 & 0 & 0 \\
\hline Calcium ammonium Nitrate & 0 & 0 & 0 & 0 & 0 & 0 \\
\hline Diammonium Phosphate & 0 & 600300 & 0 & 198 & 0 & 0 \\
\hline Liquid Ammonium Polyphosphate & 16539 & 0 & 0 & 110 & 0 & 0 \\
\hline Miscellaneous & 178 & 66870 & 914 & 0 & 265 & 0 \\
\hline Mix & 10193 & 2302 & 8184 & 2357 & 30 & 0 \\
\hline Monoammonium Phosphate & 50930 & 452960 & 0 & 21610 & 0 & 0 \\
\hline Nitrogen Solutions & 435500 & 476000 & 0 & 0 & 0 & 0 \\
\hline Potassium Nitrate & 0 & 0 & 0 & 0 & 0 & 0 \\
\hline Urea & 0 & 1612400 & 0 & 0 & 0 & 0 \\
\hline \multicolumn{7}{|l|}{ Wild Animals } \\
\hline Black bear & 23 & 16 & 25 & 43 & 23 & 14 \\
\hline Grizzly bear & 7 & 5 & 8 & 14 & 7 & 4 \\
\hline Deer & 22261 & 24230 & 42372 & 39008 & 31872 & 44562 \\
\hline Elk & 4889 & 4533 & 342 & 10081 & 2249 & 0 \\
\hline Antelope & 43047 & 4385 & 38891 & 42990 & 31019 & 13316 \\
\hline
\end{tabular}




\section{Appendix B}

\begin{tabular}{|c|c|c|c|c|c|c|}
\hline SOURCE & ALBANY & BIG HORN & CAMPBELL & CARBON & CONVERSE & CROOK \\
\hline Vehicles with catalysts & 777136 & 251123 & 630549 & 966138 & 443275 & 355992 \\
\hline Vehicles without catalysts & 289058 & 93405 & 234534 & 359357 & 164878 & 132411 \\
\hline \multicolumn{7}{|l|}{ Wildfires } \\
\hline Wildfire & 2257 & 1454.1 & 688.2 & 3367 & 1180.3 & 2682.5 \\
\hline \multicolumn{7}{|l|}{ Industry } \\
\hline Industry & 0 & 5060 & 2 & 4400 & 0 & 0 \\
\hline \multicolumn{7}{|l|}{ POTWs } \\
\hline POTWs & 3.99 & 0.993 & 3.55 & 2.5 & 1.15 & 0.346 \\
\hline \multicolumn{7}{|l|}{ Humans } \\
\hline Human population & 31742 & 11212 & 36110 & 15346 & 12433 & 5929 \\
\hline \multicolumn{7}{|l|}{ Domestic Animals } \\
\hline Dogs & 8720 & 3220 & 9150 & 4460 & 3430 & 1650 \\
\hline Cats & 10300 & 3810 & 10800 & 5270 & 4050 & 1950 \\
\hline \multicolumn{7}{|l|}{ Biogenic Soil } \\
\hline County Land Area & 11200 & 8230 & 12400 & 20700 & 11000 & 7370 \\
\hline Unknown (0) & 0 & 0 & 0 & 0 & 0 & 0 \\
\hline Urban or built upland (11-17) & 49 & 16 & 35 & 64 & 31 & 16 \\
\hline \multicolumn{7}{|l|}{ Agricultural land } \\
\hline 21-Cropland and Pasture & 527 & 727 & 1090 & 847 & 606 & 916 \\
\hline 22-Orchards, groves, nurseries & 0 & 0 & 0 & 0 & 0 & 0 \\
\hline 23-Confined feeding operations & 0 & 0 & 0 & 0 & 0 & 0 \\
\hline 24- Other agricultural land & 2 & 1 & 6 & 6 & 2 & 2 \\
\hline Rangeland(31-33) & 8290 & 5840 & 10600 & 16300 & 9200 & 3760 \\
\hline Forestland (41-43) & 2180 & 1410 & 667 & 3250 & 1140 & 2590 \\
\hline Water (51-54) & 82 & 35 & 4 & 135 & 13 & 44 \\
\hline Wetland (61-62) & 20 & 68 & 10 & 77 & 1 & 0 \\
\hline \multicolumn{7}{|l|}{ Barren land } \\
\hline 71-Dry salt flats & 0 & 0 & 5 & 0 & 2 & 0 \\
\hline 72- Beaches & 0 & 0 & 0 & 0 & 0 & 0 \\
\hline 73- Sandy areas not beaches & 0 & 0 & 0 & 28 & 0 & 0 \\
\hline 74- Bare exposed rock & 0 & 0 & 0 & 0 & 1 & 0 \\
\hline 75- Strip mines, quarries, gravel & 4 & 8 & 7 & 36 & 20 & 31 \\
\hline 76-Transitional areas & 2 & 0 & 5 & 7 & 2 & 3 \\
\hline 77- Mixed barren land & 0 & 0 & 0 & 0 & 0 & 0 \\
\hline Tundra (81-85) & 34 & 130 & 0 & 11 & 0 & 0 \\
\hline
\end{tabular}




\section{Appendix B}

\begin{tabular}{|c|c|c|c|c|c|c|}
\hline SOURCE & ALBANY & BIG HORN & CAMPBELL & CARBON & CONVERSE & CROOK \\
\hline Perennial snow or ice (91-92) & 0 & 0 & 0 & 0 & 0 & 0 \\
\hline SOURCE & FREMONT & GOSHEN & HOT SPRINGS & JOHNSON & LARAMIE & LINCOLN \\
\hline \multicolumn{7}{|l|}{ Livestock } \\
\hline Beef cows & 61687 & 46435 & 19306 & 37249 & 40588 & 20607 \\
\hline Heifers & 25504 & 45843 & 10584 & 15644 & 29576 & 9066 \\
\hline Steers & 24272 & 67735 & 6045 & 9815 & 27398 & 7552 \\
\hline Milk cows & 192 & 86 & 6 & 20 & 351 & 2188 \\
\hline Boilers & 221 & 114 & 54 & 54 & 178 & 54 \\
\hline Layers & 1030 & 1120 & 186 & 321 & 544 & 1030 \\
\hline Pullets 13 to 20 weeks & 100 & 118 & 206 & 206 & 76 & 47 \\
\hline Pullets younger than 13 weeks & 37 & 37 & 0 & 37 & 80 & 37 \\
\hline Hogs and pigs & 224 & 112 & 111 & 56 & 75500 & 1970 \\
\hline Horses & 6760 & 1390 & 1290 & 2460 & 1720 & 2980 \\
\hline Milk goats & 34 & 74 & 18 & 18 & 20 & 18 \\
\hline Sheep & 40500 & 4800 & 1180 & 74200 & 47900 & 29400 \\
\hline \multicolumn{7}{|l|}{ Fertilizer } \\
\hline Ammonium Nitrate & 960200 & 195840 & 0 & 373 & 754200 & 19486 \\
\hline Ammonium Sulfate & 122860 & 38280 & 0 & 0 & 86374 & 0 \\
\hline Ammonium Thiosulfate & 0 & 81220 & 0 & 132 & 54860 & 0 \\
\hline Anhydrous Ammonia & 238050 & 1463800 & 0 & 0 & 30947000 & 0 \\
\hline Aqueous Ammonia & 0 & 28070 & 0 & 0 & 0 & 0 \\
\hline Calcium ammonium Nitrate & 0 & 0 & 0 & 0 & 0 & 0 \\
\hline Diammonium Phosphate & 602300 & 218020 & 0 & 198 & 397 & 0 \\
\hline Liquid Ammonium Polyphosphate & 10034 & 39268 & 0 & 0 & 2802 & 0 \\
\hline Miscellaneous & 47012 & 322150 & 265 & 179 & 14421 & 0 \\
\hline Mix & 151 & 12032 & 1422 & 0 & 69880 & 0 \\
\hline Monoammonium Phosphate & 371980 & 250750 & 0 & 16640 & 174430 & 0 \\
\hline Nitrogen Solutions & 285250 & 1978200 & 0 & 0 & 8737000 & 0 \\
\hline Potassium Nitrate & 0 & 0 & 0 & 0 & 0 & 0 \\
\hline Urea & 318190 & 293550 & 0 & 452690 & 137430 & 0 \\
\hline \multicolumn{7}{|l|}{ Wild Animals } \\
\hline Black bear & 46 & 9 & 11 & 22 & 12 & 21 \\
\hline Grizzly bear & 15 & 3 & 3 & 7 & 4 & 7 \\
\hline Deer & 16566 & 9150 & 18479 & 26524 & 17918 & 43439 \\
\hline Elk & 9338 & 100 & 3325 & 652 & 0 & 3973 \\
\hline
\end{tabular}




\section{Appendix B}

\begin{tabular}{|c|c|c|c|c|c|c|}
\hline SOURCE & FREMONT & GOSHEN & HOT SPRINGS & JOHNSON & LARAMIE & LINCOLN \\
\hline Antelope & 19212 & 5238 & 3569 & 30382 & 8487 & 15607 \\
\hline \multicolumn{7}{|l|}{ Motor Vehicles } \\
\hline Vehicles with catalysts & 648515 & 226882 & 108467 & 448133 & 1263819 & 416606 \\
\hline Vehicles without catalysts & 241218 & 84387 & 40344 & 166684 & 470079 & 154957 \\
\hline \multicolumn{7}{|l|}{ Wildfires } \\
\hline Wildfire & 3959 & 136.16 & 728.9 & 2164.5 & 83.99 & 3030.3 \\
\hline \multicolumn{7}{|l|}{ Industry } \\
\hline Industry & 0 & 25500 & 0 & 0 & 170000 & 1680 \\
\hline \multicolumn{7}{|l|}{ POTWs } \\
\hline POTWs & 3.31 & 0.505 & 0.5 & 0.708 & 8.42 & 0.934 \\
\hline \multicolumn{7}{|l|}{ Humans } \\
\hline Human population & 36113 & 12244 & 4701 & 7374 & 82894 & 14890 \\
\hline \multicolumn{7}{|l|}{ Domestic Animals } \\
\hline Dogs & 10300 & 3610 & 1300 & 1910 & 22600 & 4000 \\
\hline Cats & 12100 & 4270 & 1540 & 2260 & 26700 & 4730 \\
\hline \multicolumn{7}{|l|}{ Biogenic Soil } \\
\hline County Land Area & 24100 & 5780 & 5130 & 10700 & 7140 & 10400 \\
\hline Unknown (0) & 1 & 0 & 0 & 0 & 0 & 0 \\
\hline Urban or built upland (11-17) & 131 & 14 & 59 & 36 & 124 & 35 \\
\hline \multicolumn{7}{|l|}{ Agricultural land } \\
\hline 21-Cropland and Pasture & 942 & 1580 & 165 & 249 & 1570 & 626 \\
\hline 22-Orchards, groves, nurseries & 0 & 0 & 0 & 0 & 0 & 0 \\
\hline 23-Confined feeding operations & 0 & 1 & 0 & 0 & 0 & 0 \\
\hline 24- Other agricultural land & 8 & 3 & 4 & 2 & 6 & 1 \\
\hline Rangeland(31-33) & 17100 & 4030 & 4120 & 8150 & 5350 & 6610 \\
\hline Forestland (41-43) & 3820 & 131 & 704 & 2090 & 81 & 2930 \\
\hline Water (51-54) & 198 & 9 & 0 & 22 & 3 & 44 \\
\hline Wetland (61-62) & 203 & 11 & 6 & 2 & 0 & 77 \\
\hline \multicolumn{7}{|l|}{ Barren land } \\
\hline 71-Dry salt flats & 0 & 0 & 0 & 0 & 0 & 0 \\
\hline 72- Beaches & 0 & 0 & 0 & 0 & 0 & 0 \\
\hline 73- Sandy areas not beaches & 25 & 0 & 0 & 0 & 0 & 2 \\
\hline 74- Bare exposed rock & 85 & 0 & 7 & 0 & 0 & 47 \\
\hline 75- Strip mines, quarries, gravel & 19 & 0 & 2 & 4 & 4 & 16 \\
\hline 76-Transitional areas & 17 & 1 & 2 & 1 & 3 & 12 \\
\hline
\end{tabular}




\section{Appendix B}

\begin{tabular}{|c|c|c|c|c|c|c|}
\hline SOURCE & FREMONT & GOSHEN & HOT SPRINGS & JOHNSON & LARAMIE & LINCOLN \\
\hline 77- Mixed barren land & 0 & 0 & 0 & 0 & 0 & 0 \\
\hline Tundra (81-85) & 1540 & 0 & 60 & 187 & 0 & 32 \\
\hline Perennial snow or ice (91-92) & 42 & 0 & 0 & 0 & 0 & 0 \\
\hline SOURCE & NATRONA & NIOBRARA & PARK & PLATTE & SHERIDAN & SUBLETTE \\
\hline \multicolumn{7}{|l|}{ Livestock } \\
\hline Beef cows & 33391 & 39211 & 27472 & 64614 & 43581 & 24538 \\
\hline Heifers & 11793 & 20421 & 19489 & 44871 & 23096 & 11566 \\
\hline Steers & 7950 & 22828 & 14536 & 45877 & 17980 & 9275 \\
\hline Milk cows & 36 & 27 & 627 & 885 & 154 & 53 \\
\hline Boilers & 54 & 0 & 65 & 188 & 48 & 54 \\
\hline Layers & 251 & 152 & 636 & 448 & 1110 & 392 \\
\hline Pullets 13 to 20 weeks & 206 & 0 & 68 & 26 & 206 & 193 \\
\hline Pullets younger than 13 weeks & 0 & 0 & 37 & 0 & 0 & 37 \\
\hline Hogs and pigs & 179 & 1970 & 466 & 1970 & 104 & 123 \\
\hline Horses & 2080 & 1170 & 3380 & 1440 & 3140 & 3020 \\
\hline Milk goats & 18 & 16 & 18 & 18 & 18 & 16 \\
\hline Sheep & 60200 & 16400 & 57000 & 1950 & 15700 & 17000 \\
\hline \multicolumn{7}{|l|}{ Fertilizer } \\
\hline Ammonium Nitrate & 586 & 0 & 1648800 & 372800 & 389550 & 323000 \\
\hline Ammonium Sulfate & 0 & 0 & 210270 & 0 & 5582 & 0 \\
\hline Ammonium Thiosulfate & 0 & 0 & 32993 & 0 & 0 & 6477 \\
\hline Anhydrous Ammonia & 0 & 0 & 72180 & 11023000 & 0 & 0 \\
\hline Aqueous Ammonia & 0 & 0 & 0 & 0 & 0 & 0 \\
\hline Calcium ammonium Nitrate & 0 & 0 & 14426 & 0 & 0 & 0 \\
\hline Diammonium Phosphate & 0 & 0 & 1201200 & 0 & 113690 & 0 \\
\hline Liquid Ammonium Polyphosphate & 9 & 0 & 42251 & 2830 & 0 & 0 \\
\hline Miscellaneous & 1761 & 0 & 487630 & 0 & 42560 & 17 \\
\hline Mix & 26697 & 0 & 4713 & 2789 & 2423 & 175310 \\
\hline Monoammonium Phosphate & 0 & 0 & 406720 & 258650 & 128840 & 2534 \\
\hline Nitrogen Solutions & 0 & 0 & 1471700 & 119290 & 45970 & 43420 \\
\hline Potassium Nitrate & 0 & 0 & 0 & 0 & 0 & 0 \\
\hline Urea & 0 & 0 & 285370 & 471000 & 0 & 0 \\
\hline \multicolumn{7}{|l|}{ Wild Animals } \\
\hline Black bear & 29 & 14 & 33 & 10 & 13 & 23 \\
\hline Grizzly bear & 9 & 4 & 11 & 3 & 4 & 7 \\
\hline
\end{tabular}




\section{Appendix B}

\begin{tabular}{|c|c|c|c|c|c|c|}
\hline SOURCE & NATRONA & NIOBRARA & PARK & PLATTE & SHERIDAN & SUBLETTE \\
\hline Deer & 13964 & 8197 & 22600 & 6737 & 37567 & 17350 \\
\hline Elk & 1856 & 124 & 17311 & 1825 & 2231 & 10125 \\
\hline Antelope & 61047 & 7756 & 5150 & 15294 & 4059 & 12282 \\
\hline \multicolumn{7}{|l|}{ Motor Vehicles } \\
\hline Vehicles with catalysts & 816184 & 136812 & 424552 & 419016 & 416091 & 202710 \\
\hline Vehicles without catalysts & 303585 & 50887 & 157912 & 155855 & 154765 & 75398 \\
\hline \multicolumn{7}{|l|}{ Wildfires } \\
\hline Wildfire & 1076.7 & 234.95 & 8547 & 518 & 1742.7 & 3293 \\
\hline \multicolumn{7}{|l|}{ Industry } \\
\hline Industry & 448 & 0 & 0 & 0 & 0 & 0 \\
\hline \multicolumn{7}{|l|}{ POTWs } \\
\hline POTWs & 7.2 & 0.168 & 3.89 & 0.604 & 2.06 & 1.35 \\
\hline \multicolumn{7}{|l|}{ Humans } \\
\hline Human population & 67336 & 2357 & 25773 & 8752 & 26678 & 5969 \\
\hline \multicolumn{7}{|l|}{ Domestic Animals } \\
\hline Dogs & 18100 & 754 & 7250 & 2400 & 7230 & 1600 \\
\hline Cats & 21400 & 891 & 8570 & 2840 & 8540 & 1900 \\
\hline \multicolumn{7}{|l|}{ Biogenic Soil } \\
\hline County Land Area & 13900 & 6800 & 17900 & 5530 & 6600 & 12800 \\
\hline Unknown (0) & 0 & 0 & 1 & 0 & 0 & 0 \\
\hline Urban or built upland (11-17) & 102 & 4 & 35 & 38 & 40 & 76 \\
\hline \multicolumn{7}{|l|}{ Agricultural land } \\
\hline 21-Cropland and Pasture & 239 & 462 & 715 & 937 & 475 & 788 \\
\hline 22-Orchards, groves, nurseries & 0 & 0 & 0 & 0 & 0 & 0 \\
\hline 23-Confined feeding operations & 0 & 0 & 1 & 1 & 0 & 0 \\
\hline 24- Other agricultural land & 2 & 3 & 2 & 1 & 1 & 1 \\
\hline Rangeland(31-33) & 12400 & 6100 & 6650 & 4000 & 4390 & 7430 \\
\hline Forestland (41-43) & 1040 & 227 & 8250 & 499 & 1690 & 3180 \\
\hline Water (51-54) & 56 & 2 & 71 & 55 & 2 & 121 \\
\hline Wetland (61-62) & 7 & 0 & 82 & 1 & 0 & 294 \\
\hline \multicolumn{7}{|l|}{ Barren land } \\
\hline 71-Dry salt flats & 0 & 0 & 0 & 0 & 0 & 0 \\
\hline 72- Beaches & 0 & 0 & 0 & 0 & 0 & 0 \\
\hline 73- Sandy areas not beaches & 1 & 0 & 1 & 1 & 0 & 16 \\
\hline 74- Bare exposed rock & 2 & 1 & 187 & 0 & 0 & 56 \\
\hline
\end{tabular}




\section{Appendix B}

\begin{tabular}{|c|c|c|c|c|c|c|}
\hline SOURCE & NATRONA & NIOBRARA & PARK & PLATTE & SHERIDAN & SUBLETTE \\
\hline 75- Strip mines, quarries, gravel & 3 & 0 & 0 & 3 & 5 & 4 \\
\hline 76-Transitional areas & 8 & 0 & 0 & 2 & 1 & 7 \\
\hline 77- Mixed barren land & 0 & 0 & 0 & 0 & 0 & 0 \\
\hline Tundra (81-85) & 0 & 0 & 1930 & 0 & 4 & 847 \\
\hline Perennial snow or ice (91-92) & 0 & 0 & 20 & 0 & 0 & 13 \\
\hline SOURCE & SWEETWATER & TETON & UINTA & WASHAKIE & WESTON & \\
\hline \multicolumn{7}{|l|}{ Livestock } \\
\hline Beef cows & 9891 & 5347 & 21554 & 13814 & 31511 & \\
\hline Heifers & 3212 & 2519 & 8099 & 7548 & 12034 & \\
\hline Steers & 3654 & 1786 & 8257 & 10610 & 13964 & \\
\hline Milk cows & 14 & 118 & 186 & 10 & 6 & \\
\hline Boilers & 0 & 0 & 76 & 54 & 54 & \\
\hline Layers & 58 & 58 & 340 & 314 & 434 & \\
\hline Pullets 13 to 20 weeks & 206 & 0 & 112 & 206 & 173 & \\
\hline Pullets younger than 13 weeks & 0 & 0 & 92 & 37 & 37 & \\
\hline Hogs and pigs & 64 & 1970 & 50 & 1970 & 118 & \\
\hline Horses & 975 & 1500 & 1810 & 777 & 1320 & \\
\hline Milk goats & 18 & 18 & 18 & 41 & 23 & \\
\hline Sheep & 11100 & 1180 & 50500 & 44100 & 4890 & \\
\hline \multicolumn{7}{|l|}{ Fertilizer } \\
\hline Ammonium Nitrate & 513 & 0 & 145970 & 1877800 & 0 & \\
\hline Ammonium Sulfate & 10417 & 0 & 42420 & 231 & 0 & \\
\hline Ammonium Thiosulfate & 0 & 0 & 0 & 1389 & 0 & \\
\hline Anhydrous Ammonia & 16161000 & 0 & 0 & 253600 & 0 & \\
\hline Aqueous Ammonia & 0 & 0 & 0 & 0 & 0 & \\
\hline Calcium ammonium Nitrate & 0 & 0 & 0 & 0 & 0 & \\
\hline Diammonium Phosphate & 0 & 0 & 0 & 746300 & 0 & \\
\hline Liquid Ammonium Polyphosphate & 0 & 0 & 0 & 22136 & 0 & \\
\hline Miscellaneous & 1922 & 295 & 8624 & 28311 & 23630 & \\
\hline Mix & 7688 & 966 & 28907 & 328 & 225 & \\
\hline Monoammonium Phosphate & 16607 & 0 & 4972 & 178970 & 0 & \\
\hline Nitrogen Solutions & 0 & 0 & 0 & 437820 & 0 & \\
\hline Potassium Nitrate & 0 & 0 & 0 & 0 & 0 & \\
\hline Urea & 36125 & 0 & 0 & 789800 & 0 & \\
\hline
\end{tabular}




\section{Appendix B}

\begin{tabular}{|c|c|c|c|c|c|}
\hline SOURCE & SWEETWATER & TETON & UINTA & WASHAKIE & WESTON \\
\hline Black bear & 58 & 21 & 11 & 12 & 13 \\
\hline Grizzly bear & 19 & 7 & 3 & 4 & 4 \\
\hline Deer & 17035 & 22035 & 21500 & 12196 & 8500 \\
\hline Elk & 3660 & 13379 & 1900 & 2302 & 0 \\
\hline Antelope & 33600 & 11925 & 8232 & 2194 & 7756 \\
\hline \multicolumn{6}{|l|}{ Motor Vehicles } \\
\hline Vehicles with catalysts & 1730221 & 416688 & 707382 & 126363 & 138875 \\
\hline Vehicles without catalysts & 643555 & 154986 & 263112 & 47002 & 51617 \\
\hline \multicolumn{6}{|l|}{ Wildfires } \\
\hline Wildfire & 1080.4 & 7733 & 521.7 & 610.5 & 791.8 \\
\hline \multicolumn{6}{|l|}{ Industry } \\
\hline Industry & 22800 & 0 & 0 & 37400 & 0 \\
\hline \multicolumn{6}{|l|}{ POTWs } \\
\hline POTWs & 2.6 & 1.34 & 1.87 & 1.14 & 0.558 \\
\hline \multicolumn{6}{|l|}{ Humans } \\
\hline Human population & 36777 & 18499 & 19536 & 8082 & 6642 \\
\hline \multicolumn{6}{|l|}{ Domestic Animals } \\
\hline Dogs & 11400 & 3920 & 5770 & 2450 & 1860 \\
\hline Cats & 13500 & 4630 & 6820 & 2890 & 2190 \\
\hline \multicolumn{6}{|l|}{ Biogenic Soil } \\
\hline County Land Area & 27200 & 11000 & 5370 & 5790 & 6250 \\
\hline Unknown (0) & 0 & 0 & 0 & 0 & 0 \\
\hline Urban or built upland (11-17) & 96 & 35 & 32 & 11 & 7 \\
\hline \multicolumn{6}{|l|}{ Agricultural land } \\
\hline 21-Cropland and Pasture & 171 & 173 & 446 & 266 & 401 \\
\hline 22-Orchards, groves, nurseries & 0 & 0 & 0 & 0 & 0 \\
\hline 23-Confined feeding operations & 0 & 0 & 0 & 0 & 0 \\
\hline 24- Other agricultural land & 2 & 0 & 0 & 2 & 2 \\
\hline Rangeland(31-33) & 25400 & 1950 & 4360 & 4920 & 5060 \\
\hline Forestland (41-43) & 1050 & 7490 & 504 & 589 & 767 \\
\hline Water (51-54) & 99 & 516 & 9 & 0 & 5 \\
\hline Wetland (61-62) & 100 & 169 & 22 & 1 & 1 \\
\hline \multicolumn{6}{|l|}{ Barren land } \\
\hline 71-Dry salt flats & 2 & 0 & 0 & 0 & 0 \\
\hline 72- Beaches & 0 & 0 & 0 & 0 & 0 \\
\hline
\end{tabular}




\section{Appendix B}

\begin{tabular}{lrrrr}
\hline SOURCE & SWEETWATER & TETON & UINTA & WASHAKIE \\
\hline 73- Sandy areas not beaches & 263 & 22 & 0 & 0 \\
74- Bare exposed rock & 20 & 84 & 0 & 0 \\
75- Strip mines, quarries, gravel & 13 & 2 & 2 & 0 \\
76-Transitional areas & 14 & 1 & 1 & 1 \\
77- Mixed barren land & 0 & 0 & 0 & 0 \\
Tundra (81-85) & 0 & 573 & 0 & 0 \\
Perennial snow or ice (91-92) & 0 & 0 & 0 & 0 \\
\hline
\end{tabular}


Appendix C

\begin{tabular}{|c|c|c|c|c|c|c|c|c|}
\hline SOURCE & ALBANY & BIG HORN & CAMPBELL & CARBON & CONVERSE & CROOK & FREMONT & GOSHEN \\
\hline \multicolumn{9}{|l|}{ Livestock } \\
\hline milk_cows & 1820 & 6700 & 900 & 289 & 5170 & 1600 & 4750 & 2120 \\
\hline beef_cows & 282000 & 298000 & 544000 & 518000 & 492000 & 324000 & 584000 & 440000 \\
\hline heifers & 144000 & 131000 & 191000 & 218000 & 168000 & 139000 & 241000 & 432000 \\
\hline steers & 134000 & 95400 & 144000 & 180000 & 140000 & 117000 & 229000 & 640000 \\
\hline hogs_and_pigs & 3290 & 10700 & 938 & 590 & 232 & 4260 & 1080 & 541 \\
\hline horses & 18600 & 20300 & 29300 & 19100 & 12800 & 22700 & 62200 & 12700 \\
\hline sheep & 5230 & 28400 & 46700 & 26600 & 53600 & 22700 & 31600 & 3740 \\
\hline angora_goats & 115 & 16 & 115 & 115 & 115 & 115 & 6 & 115 \\
\hline milk_goats & 13 & 43 & 69 & 13 & 17 & 13 & 24 & 52 \\
\hline pullets_It_13 & 0 & 9 & 0 & 0 & 0 & 9 & 9 & 9 \\
\hline pullets_13_to_20 & 50 & 16 & 21 & 50 & 12 & 7 & 24 & 29 \\
\hline layers & 93 & 106 & 156 & 49 & 101 & 96 & 250 & 271 \\
\hline broilers & 13 & 22 & 11 & 0 & 13 & 19 & 54 & 28 \\
\hline turkeys & 6 & 23 & 23 & 23 & 23 & 23 & 76 & 23 \\
\hline geese & 36 & 61 & 120 & 12 & 24 & 67 & 29 & 23 \\
\hline ducks & 11 & 10 & 78 & 11 & 11 & 35 & 130 & 19 \\
\hline \multicolumn{9}{|l|}{ Fertilizer } \\
\hline $\operatorname{mix}$ & 371 & 84 & 298 & 86 & 1 & 0 & 6 & 438 \\
\hline anhydrous_ammonia & 0 & 0 & 0 & 0 & 0 & 0 & 11600 & 71100 \\
\hline aqueous_ammonia & 0 & 0 & 0 & 0 & 0 & 0 & 0 & 1360 \\
\hline ammonium_nitrate & 3760 & 53800 & 0 & 2510 & 0 & 0 & 35000 & 7120 \\
\hline ammonium_sulfate & 0 & 0 & 0 & 1010 & 0 & 0 & 22400 & 6970 \\
\hline ammonium_thiosulfate & 0 & 140 & 102 & 0 & 16 & 0 & 0 & 2460 \\
\hline calcium_ammonium_nitrate & 0 & 0 & 0 & 0 & 0 & 0 & 0 & 0 \\
\hline nitrogen_solutions & 42300 & 46300 & 0 & 0 & 0 & 0 & 27700 & 192000 \\
\hline urea & 0 & 392000 & 0 & 0 & 0 & 0 & 77300 & 71300 \\
\hline diammonium_phosphate & 0 & 36400 & 0 & 12 & 0 & 0 & 36600 & 13200 \\
\hline monoammonium_phosphate & 3090 & 27500 & 0 & 1310 & 0 & 0 & 22600 & 15200 \\
\hline liquid_ammonium_polyphosphate & 1000 & 0 & 0 & 7 & 0 & 0 & 609 & 2390 \\
\hline potassium_nitrate & 0 & 0 & 0 & 0 & 0 & 0 & 0 & 0 \\
\hline miscellaneous & 17 & 6500 & 89 & 0 & 26 & 0 & 4570 & 31300 \\
\hline \multicolumn{9}{|l|}{ Wild Animals } \\
\hline grizzly_bears & 1330 & 923 & 1440 & 2500 & 1320 & 814 & 2680 & 529 \\
\hline black bears & 1510 & 1050 & 1630 & 2820 & 1500 & 919 & 3040 & 600 \\
\hline
\end{tabular}


Appendix C

\begin{tabular}{|c|c|c|c|c|c|c|c|c|}
\hline SOURCE & ALBANY & BIG HORN & CAMPBELL & CARBON & CONVERSE & CROOK & FREMONT & GOSHEN \\
\hline elk & 83900 & 77800 & 5870 & 173000 & 38600 & 0 & 161000 & 1720 \\
\hline deer & 106237 & 115289 & 201994 & 185796 & 151972 & 212474 & 79082 & 43591 \\
\hline antelope & 122000 & 12500 & 111000 & 122000 & 88600 & 38000 & 54800 & 15000 \\
\hline \multicolumn{9}{|l|}{ Motor Vehicles } \\
\hline cars & 746 & 241 & 606 & 928 & 425 & 342 & 623 & 218 \\
\hline trucks & 1740 & 560 & 1420 & 2160 & 990 & 792 & 1450 & 506 \\
\hline \multicolumn{9}{|l|}{ Wildfires } \\
\hline wildfire & 29600 & 19100 & 9020 & 44200 & 15500 & 35200 & 52000 & 1790 \\
\hline \multicolumn{9}{|l|}{ Industry } \\
\hline industry & 0 & 5060 & 2 & 4400 & 0 & 0 & 0 & 25500 \\
\hline \multicolumn{9}{|l|}{ POTWs } \\
\hline potws & 79 & 20 & 70 & 49 & 23 & 7 & 65 & 10 \\
\hline \multicolumn{9}{|l|}{ Humans } \\
\hline humans & 13900 & 4930 & 15800 & 6740 & 5460 & 2620 & 15800 & 5380 \\
\hline \multicolumn{9}{|l|}{ Domestic Animals } \\
\hline cats & 7100 & 2630 & 7450 & 3640 & 2800 & 1340 & 8350 & 2950 \\
\hline dogs & 19100 & 7030 & 20000 & 9740 & 7490 & 3600 & 22400 & 7880 \\
\hline \multicolumn{9}{|l|}{ Biogenic Soil } \\
\hline lu0 -unknown & 22 & 0 & 86 & 17 & 0 & 0 & 288 & 0 \\
\hline lu11 - residential & 2570 & 1310 & 1030 & 1680 & 1490 & 316 & 3920 & 1130 \\
\hline lu12 - commercial and services & 1030 & 458 & 899 & 586 & 421 & 78 & 1340 & 422 \\
\hline lu13 - industrial & 217 & 238 & 484 & 3140 & 431 & 52 & 12400 & 115 \\
\hline lu14 - transportation, utilities & 3110 & 388 & 2960 & 3780 & 2170 & 1920 & 1150 & 232 \\
\hline lu16 - mixed urban or built-up & 126 & 121 & 13 & 460 & 154 & 22 & 682 & 164 \\
\hline lu17 - other urban or built-up & 827 & 88 & 179 & 628 & 230 & 85 & 1400 & 173 \\
\hline lu21 - cropland and pasture & 632000 & 872000 & 1310000 & 1020000 & 727000 & 1100000 & 1130000 & 1900000 \\
\hline lu22 - orchards, groves, nurseries & 0 & 0 & 125 & 0 & 0 & 0 & 0 & 0 \\
\hline lu24 - other agricultural land & 2480 & 1110 & 7120 & 7320 & 2340 & 2120 & 9340 & 3320 \\
\hline lu31 - herbaceous rangeland & 1050000 & 3620 & 2000000 & 87600 & 1810000 & 950000 & 12100 & 1200000 \\
\hline lu32 - shrub and brush rangeland & 102000 & 282000 & 91000 & 4920000 & 148000 & 3520 & 4360000 & 0 \\
\hline lu33 - mixed rangeland & 1920000 & 1870000 & 1820000 & 990000 & 1440000 & 436000 & 1930000 & 287000 \\
\hline lu41 - deciduous forest land & 263 & 2820 & 1540 & 46200 & 4280 & 1430 & 5020 & 3730 \\
\hline lu42 - evergreen forest land & 296000 & 192000 & 92200 & 353000 & 154000 & 362000 & 486000 & 14800 \\
\hline lu43 - mixed forest land & 9440 & 2530 & 0 & 58900 & 2280 & 0 & 44300 & 0 \\
\hline lu61 - forested wetland & 2060 & 22300 & 0 & 19600 & 0 & 0 & 20000 & 3460 \\
\hline
\end{tabular}


Appendix C

\begin{tabular}{|c|c|c|c|c|c|c|c|c|}
\hline SOURCE & ALBANY & BIG HORN & CAMPBELL & CARBON & CONVERSE & CROOK & FREMONT & GOSHEN \\
\hline lu62 - non forested wetland & 5470 & 2800 & 3620 & 8800 & 318 & 0 & 55100 & 418 \\
\hline lu71 - dry salt flats & 0 & 0 & 32 & 0 & 11 & 3 & 3 & 0 \\
\hline lu76 - transitional areas & 791 & 18 & 1960 & 2560 & 673 & 1080 & 6100 & 299 \\
\hline lu77 - mixed barren land & 0 & 0 & 0 & 0 & 0 & 0 & 0 & 0 \\
\hline SOURCE & HOT SPRINGS & JOHNSON & LARAMIE & LINCOLN & NATRONA & NIOBRARA & PARK & PLATTE \\
\hline \multicolumn{9}{|l|}{ Livestock } \\
\hline milk_cows & 160 & 497 & 8680 & 54100 & 880 & 670 & 15500 & 21800 \\
\hline beef_cows & 182000 & 353000 & 385000 & 196000 & 317000 & 372000 & 260000 & 612000 \\
\hline heifers & 100000 & 148000 & 280000 & 85700 & 111000 & 193000 & 184000 & 424000 \\
\hline steers & 57000 & 92600 & 259000 & 71300 & 75100 & 215000 & 137000 & 433000 \\
\hline hogs_and_pigs & 536 & 271 & 365000 & 9530 & 865 & 9530 & 2260 & 9530 \\
\hline horses & 11900 & 22600 & 15800 & 27400 & 19100 & 10800 & 31100 & 13200 \\
\hline sheep & 920 & 57800 & 37300 & 22900 & 46900 & 12800 & 44500 & 1520 \\
\hline angora goats & 115 & 115 & 115 & 115 & 30 & 115 & 115 & 115 \\
\hline milk_goats & 13 & 13 & 14 & 13 & 13 & 11 & 13 & 13 \\
\hline pullets_It_13 & 0 & 9 & 19 & 9 & 0 & 0 & 9 & 0 \\
\hline pullets_13_to_20 & 50 & 50 & 19 & 11 & 50 & 0 & 16 & 6 \\
\hline layers & 45 & 78 & 132 & 250 & 61 & 37 & 154 & 109 \\
\hline broilers & 13 & 13 & 43 & 13 & 13 & 0 & 16 & 46 \\
\hline turkeys & 0 & 23 & 18 & 23 & 11 & 0 & 87 & 0 \\
\hline geese & 14 & 12 & 29 & 21 & 25 & 12 & 30 & 12 \\
\hline ducks & 6 & 6 & 15 & 15 & 10 & 11 & 33 & 53 \\
\hline \multicolumn{9}{|l|}{ Fertilizer } \\
\hline $\operatorname{mix}$ & 52 & 0 & 2550 & 0 & 972 & 0 & 172 & 102 \\
\hline anhydrous_ammonia & 0 & 0 & 1500000 & 0 & 0 & 0 & 3500 & 535000 \\
\hline aqueous_ammonia & 0 & 0 & 0 & 0 & 0 & 0 & 0 & 0 \\
\hline ammonium_nitrate & 0 & 14 & 27500 & 710 & 21 & 0 & 60100 & 13600 \\
\hline ammonium_sulfate & 0 & 0 & 15700 & 0 & 0 & 0 & 38300 & 0 \\
\hline ammonium_thiosulfate & 0 & 4 & 1670 & 0 & 0 & 0 & 1000 & 0 \\
\hline calcium_ammonium_nitrate & 0 & 0 & 0 & 0 & 0 & 0 & 526 & 0 \\
\hline nitrogen_solutions & 0 & 0 & 849000 & 0 & 0 & 0 & 143000 & 11600 \\
\hline urea & 0 & 110000 & 33400 & 0 & 0 & 0 & 69200 & 114000 \\
\hline diammonium_phosphate & 0 & 12 & 24 & 0 & 0 & 0 & 72900 & 0 \\
\hline monoammonium phosphate & 0 & 1010 & 10600 & 0 & 0 & 0 & 24700 & 15700 \\
\hline liquid_ammonium_polyphosphate & 0 & 0 & 170 & 0 & 1 & 0 & 2570 & 172 \\
\hline
\end{tabular}


Appendix C

\begin{tabular}{|c|c|c|c|c|c|c|c|c|}
\hline SOURCE & HOT SPRINGS & JOHNSON & LARAMIE & LINCOLN & NATRONA & NIOBRARA & PARK & PLATTE \\
\hline potassium_nitrate & 0 & 0 & 0 & 0 & 0 & 0 & 0 & 0 \\
\hline miscellaneous & 26 & 17 & 1400 & 0 & 171 & 0 & 47400 & 0 \\
\hline \multicolumn{9}{|l|}{ Wild Animals } \\
\hline grizzly_bears & 614 & 1310 & 694 & 1220 & 1720 & 804 & 1920 & 572 \\
\hline black_bears & 695 & 1480 & 787 & 1390 & 1930 & 912 & 2170 & 649 \\
\hline elk & 57100 & 11200 & 0 & 68200 & 31900 & 2120 & 296000 & 31400 \\
\hline deer & 88134 & 126246 & 85276 & 206758 & 66696 & 39065 & 107666 & 32109 \\
\hline antelope & 10200 & 86900 & 24200 & 44500 & 174000 & 22200 & 14800 & 43700 \\
\hline \multicolumn{9}{|l|}{ Motor Vehicles } \\
\hline cars & 104 & 430 & 1210 & 401 & 784 & 132 & 408 & 402 \\
\hline trucks & 242 & 1000 & 2820 & 930 & 1820 & 305 & 948 & 936 \\
\hline \multicolumn{9}{|l|}{ Wildfires } \\
\hline wildfire & 9560 & 28400 & 1100 & 39700 & 14200 & 3080 & 112000 & 6790 \\
\hline \multicolumn{9}{|l|}{ Industry } \\
\hline industry & 0 & 0 & 170000 & 1682 & 448 & 0 & 0 & 0 \\
\hline \multicolumn{9}{|l|}{ POTWs } \\
\hline potws & 10 & 14 & 166 & 18 & 142 & 3 & 77 & 12 \\
\hline \multicolumn{9}{|l|}{ Humans } \\
\hline humans & 2060 & 3240 & 36500 & 6560 & 29600 & 1010 & 11400 & 3840 \\
\hline \multicolumn{9}{|l|}{ Domestic Animals } \\
\hline cats & 1060 & 1560 & 18500 & 3260 & 14800 & 614 & 5920 & 1960 \\
\hline dogs & 2840 & 4180 & 49300 & 8740 & 39500 & 1640 & 15800 & 5240 \\
\hline \multicolumn{9}{|l|}{ Biogenic Soil } \\
\hline lu0 -unknown & 0 & 9 & 0 & 14 & 110 & 0 & 234 & 3 \\
\hline lu11 - residential & 474 & 551 & 6670 & 862 & 5810 & 352 & 1490 & 1080 \\
\hline lu12 - commercial and services & 185 & 137 & 4100 & 352 & 2270 & 42 & 1000 & 391 \\
\hline lu13 - industrial & 8260 & 203 & 416 & 2330 & 3520 & 44 & 1880 & 686 \\
\hline lu14 - transportation, utilities & 99 & 4550 & 6320 & 1100 & 3250 & 72 & 594 & 3200 \\
\hline lu16 - mixed urban or built-up & 386 & 232 & 446 & 506 & 420 & 124 & 253 & 328 \\
\hline lu17 - other urban or built-up & 64 & 144 & 1800 & 388 & 980 & 80 & 401 & 344 \\
\hline lu21 - cropland and pasture & 198000 & 299000 & 1880000 & 751000 & 287000 & 554000 & 858000 & 1120000 \\
\hline lu22 - orchards, groves, nurseries & 0 & 0 & 0 & 0 & 0 & 0 & 0 & 442 \\
\hline lu24 - other agricultural land & 4370 & 2240 & 7270 & 1730 & 2050 & 3380 & 2210 & 1700 \\
\hline lu31 - herbaceous rangeland & 226 & 19300 & 1700000 & 3020 & 677 & 1900000 & 143000 & 492000 \\
\hline lu32 - shrub and brush rangeland & 1110000 & 647000 & 14600 & 2380000 & 2170000 & 13300 & 906000 & 35300 \\
\hline
\end{tabular}


Appendix C

\begin{tabular}{|c|c|c|c|c|c|c|c|c|}
\hline SOURCE & HOT SPRINGS & JOHNSON & LARAMIE & LINCOLN & NATRONA & NIOBRARA & PARK & PLATTE \\
\hline lu33 - mixed rangeland & 414000 & 2350000 & 258000 & 69500 & 2410000 & 344000 & 1420000 & 950000 \\
\hline lu41 - deciduous forest land & 1140 & 10400 & 0 & 7270 & 1510 & 5880 & 3300 & 494 \\
\hline lu42 - evergreen forest land & 87700 & 280000 & 11400 & 280000 & 140000 & 25900 & 1140000 & 69600 \\
\hline lu43 - mixed forest land & 9970 & 4020 & 0 & 125000 & 4400 & 0 & 12400 & 0 \\
\hline lu61 - forested wetland & 2100 & 108 & 0 & 7180 & 0 & 0 & 11200 & 0 \\
\hline lu62 - non forested wetland & 294 & 544 & 0 & 21500 & 2580 & 178 & 19100 & 400 \\
\hline lu71 - dry salt flats & 0 & 0 & 0 & 0 & 3 & 0 & 2 & 0 \\
\hline lu76 - transitional areas & 769 & 484 & 1060 & 4510 & 3110 & 0 & 172 & 625 \\
\hline lu77 - mixed barren land & 28 & 0 & 0 & 0 & 0 & 0 & 14 & 0 \\
\hline SOURCE & SHERIDAN & SUBLETTE & SWEETWATER & TETON & UINTA & WASHAKIE & WESTON & WYOMING \\
\hline \multicolumn{9}{|l|}{ Livestock } \\
\hline milk_cows & 3800 & 1320 & 334 & 2920 & 4600 & 245 & 155 & 139010 \\
\hline beef_cows & 413000 & 233000 & 93700 & 50800 & 205000 & 131000 & 299000 & 7584500 \\
\hline heifers & 218000 & 110000 & 30400 & 23800 & 76400 & 71300 & 113000 & 3832600 \\
\hline steers & 170000 & 87600 & 34400 & 16900 & 78000 & 100000 & 132000 & 3638300 \\
\hline hogs_and_pigs & 503 & 595 & 310 & 9530 & 242 & 9530 & 571 & 440434 \\
\hline horses & 28900 & 27700 & 8960 & 13800 & 16700 & 7140 & 12100 & 464900 \\
\hline sheep & 12200 & 13300 & 8660 & 920 & 39400 & 34400 & 3820 & 555910 \\
\hline angora_goats & 115 & 115 & 115 & 115 & 115 & 115 & 115 & 2352 \\
\hline milk_goats & 13 & 11 & 13 & 13 & 13 & 29 & 16 & 450 \\
\hline pullets_It_13 & 0 & 9 & 0 & 0 & 22 & 9 & 9 & 131 \\
\hline pullets_13_to_20 & 50 & 47 & 50 & 0 & 27 & 50 & 42 & 677 \\
\hline layers & 269 & 95 & 14 & 14 & 82 & 76 & 105 & 2643 \\
\hline broilers & 12 & 13 & 0 & 0 & 19 & 13 & 13 & 385 \\
\hline turkeys & 9 & 25 & 0 & 0 & 16 & 23 & 6 & 462 \\
\hline geese & 33 & 12 & 10 & 12 & 12 & 12 & 12 & 630 \\
\hline ducks & 11 & 11 & 11 & 11 & 39 & 11 & 11 & 559 \\
\hline \multicolumn{9}{|l|}{ Fertilizer } \\
\hline $\operatorname{mix}$ & 88 & 6390 & 280 & 35 & 1050 & 12 & 8 & 12995 \\
\hline anhydrous_ammonia & 0 & 0 & 784000 & 0 & 0 & 12300 & 0 & 2917500 \\
\hline aqueous_ammonia & 0 & 0 & 0 & 0 & 0 & 0 & 0 & 1360 \\
\hline ammonium_nitrate & 14200 & 11800 & 19 & 0 & 5320 & 68400 & 0 & 303874 \\
\hline ammonium_sulfate & 1020 & 0 & 1900 & 0 & 7730 & 42 & 0 & 95072 \\
\hline ammonium_thiosulfate & 0 & 197 & 0 & 0 & 0 & 42 & 0 & 5631 \\
\hline calcium_ammonium_nitrate & 0 & 0 & 0 & 0 & 0 & 0 & 0 & 526 \\
\hline
\end{tabular}


Appendix C

\begin{tabular}{|c|c|c|c|c|c|c|c|c|}
\hline SOURCE & SHERIDAN & SUBLETTE & SWEETWATER & TETON & UINTA & WASHAKIE & WESTON & WYOMING \\
\hline nitrogen_solutions & 4460 & 4220 & 0 & 0 & 0 & 42500 & 0 & 1363080 \\
\hline urea & 0 & 0 & 8780 & 0 & 0 & 192000 & 0 & 1067980 \\
\hline diammonium_phosphate & 6900 & 0 & 0 & 0 & 0 & 45300 & 0 & 211348 \\
\hline monoammonium_phosphate & 7820 & 154 & 1010 & 0 & 302 & 10900 & 0 & 141896 \\
\hline liquid_ammonium_polyphosphate & 0 & 0 & 0 & 0 & 0 & 1340 & 0 & 8258 \\
\hline potassium_nitrate & 0 & 0 & 0 & 0 & 0 & 0 & 0 & 0 \\
\hline miscellaneous & 4140 & 2 & 187 & 29 & 838 & 2750 & 2300 & 101761 \\
\hline \multicolumn{9}{|l|}{ Wild Animals } \\
\hline grizzly_bears & 773 & 1370 & 3400 & 1210 & 618 & 702 & 743 & 29206 \\
\hline black_bears & 880 & 1540 & 3850 & 1380 & 701 & 793 & 840 & 33066 \\
\hline elk & 38300 & 173000 & 62800 & 230000 & 32600 & 39500 & 0 & 1616010 \\
\hline deer & 179126 & 82894 & 80988 & 104808 & 102426 & 58121 & 40494 & 2497241 \\
\hline antelope & 11600 & 35200 & 96000 & 34000 & 23500 & 6250 & 22200 & 1213150 \\
\hline \multicolumn{9}{|l|}{ Motor Vehicles } \\
\hline cars & 400 & 194 & 1660 & 401 & 679 & 121 & 133 & 11588 \\
\hline trucks & 930 & 452 & 3860 & 930 & 1580 & 282 & 310 & 26963 \\
\hline \multicolumn{9}{|l|}{ Wildfires } \\
\hline wildfire & 22800 & 43200 & 14200 & 101000 & 6840 & 8000 & 10400 & 627680 \\
\hline \multicolumn{9}{|l|}{ Industry } \\
\hline industry & 0 & 0 & 22818 & 0 & 0 & 37409 & 0 & 267319 \\
\hline \multicolumn{9}{|l|}{ POTWs } \\
\hline potws & 41 & 27 & 51 & 26 & 37 & 23 & 11 & 979 \\
\hline \multicolumn{9}{|l|}{ Humans } \\
\hline humans & 11800 & 2750 & 16400 & 8200 & 8720 & 3540 & 2950 & 219200 \\
\hline \multicolumn{9}{|l|}{ Domestic Animals } \\
\hline cats & 5890 & 1310 & 9310 & 3190 & 4700 & 1990 & 1510 & 111834 \\
\hline dogs & 15800 & 3490 & 24800 & 8560 & 12600 & 5350 & 4070 & 299150 \\
\hline \multicolumn{9}{|l|}{ Biogenic Soil } \\
\hline lu0 -unknown & 84 & 68 & 74 & 42 & 0 & 82 & 18 & 1151 \\
\hline lu11 - residential & 2860 & 749 & 2280 & 2620 & 1390 & 624 & 439 & 41697 \\
\hline lu12 - commercial and services & 1160 & 232 & 920 & 1380 & 358 & 137 & 202 & 18100 \\
\hline lu13 - industrial & 164 & 10200 & 4150 & 0 & 736 & 512 & 204 & 50382 \\
\hline lu14 - transportation, utilities & 1520 & 287 & 6000 & 253 & 2350 & 204 & 139 & 45648 \\
\hline lu16 - mixed urban or built-up & 401 & 143 & 811 & 103 & 150 & 260 & 49 & 6354 \\
\hline lu17 - other urban or built-up & 248 & 466 & 1070 & 1210 & 182 & 75 & 8 & 11070 \\
\hline
\end{tabular}


Appendix C

\begin{tabular}{|c|c|c|c|c|c|c|c|c|}
\hline SOURCE & SHERIDAN & SUBLETTE & SWEETWATER & TETON & UINTA & WASHAKIE & WESTON & WYOMING \\
\hline lu21 - cropland and pasture & 570000 & 946000 & 205000 & 208000 & 535000 & 319000 & 481000 & 17902000 \\
\hline lu22 - orchards, groves, nurseries & 0 & 0 & 0 & 0 & 0 & 0 & 0 & 567 \\
\hline lu24 - other agricultural land & 667 & 1050 & 2110 & 149 & 199 & 2990 & 2230 & 69495 \\
\hline lu31 - herbaceous rangeland & 12700 & 23200 & 1220 & 36700 & 264 & 592 & 1370000 & 12816219 \\
\hline lu32 - shrub and brush rangeland & 52100 & 2530000 & 9240000 & 632000 & 1580000 & 1200000 & 31000 & 32447820 \\
\hline lu33 - mixed rangeland & 1560000 & 190000 & 117000 & 51700 & 19700 & 620000 & 476000 & 21942900 \\
\hline lu41 - deciduous forest land & 4100 & 8090 & 1850 & 377 & 12200 & 1050 & 1240 & 124184 \\
\hline lu42 - evergreen forest land & 221000 & 329000 & 142000 & 998000 & 45600 & 79900 & 106000 & 5906100 \\
\hline lu43 - mixed forest land & 11600 & 110000 & 2590 & 52900 & 13000 & 1880 & 0 & 465210 \\
\hline lu61 - forested wetland & 0 & 39100 & 4550 & 26800 & 7940 & 50 & 296 & 166744 \\
\hline lu62 - non forested wetland & 167 & 69100 & 32400 & 35500 & 0 & 174 & 0 & 258463 \\
\hline lu71 - dry salt flats & 0 & 0 & 16 & 0 & 0 & 0 & 0 & 71 \\
\hline lu76 - transitional areas & 384 & 2650 & 5210 & 193 & 436 & 0 & 0 & 33084 \\
\hline lu77 - mixed barren land & 0 & 0 & 0 & 0 & 0 & 0 & 0 & 41 \\
\hline
\end{tabular}


Appendix D

\begin{tabular}{|c|c|c|c|c|c|c|c|c|c|c|c|c|}
\hline COUNTY & JAN & FEB & MAR & APR & MAY & JUN & JUL & AUG & SEP & OCT & NOV & DEC \\
\hline \multicolumn{13}{|l|}{ Urea } \\
\hline Big Horn & 0.030 & 0.027 & 0.151 & 0.183 & 0.100 & 0.095 & 0.078 & 0.069 & 0.143 & 0.035 & 0.044 & 0.044 \\
\hline Fremont & 0.022 & 0.020 & 0.113 & 0.137 & 0.075 & 0.071 & 0.106 & 0.094 & 0.195 & 0.048 & 0.059 & 0.060 \\
\hline Goshen & 0.035 & 0.033 & 0.182 & 0.220 & 0.121 & 0.114 & 0.056 & 0.050 & 0.102 & 0.025 & 0.031 & 0.032 \\
\hline Johnson & 0.039 & 0.036 & 0.198 & 0.239 & 0.132 & 0.124 & 0.044 & 0.039 & 0.081 & 0.020 & 0.025 & 0.025 \\
\hline Laramie & 0.024 & 0.022 & 0.121 & 0.146 & 0.080 & 0.076 & 0.100 & 0.090 & 0.184 & 0.045 & 0.056 & 0.057 \\
\hline Park & 0.024 & 0.022 & 0.122 & 0.148 & 0.081 & 0.077 & 0.099 & 0.088 & 0.182 & 0.045 & 0.056 & 0.056 \\
\hline Platte & 0.029 & 0.026 & 0.146 & 0.177 & 0.097 & 0.092 & 0.082 & 0.073 & 0.150 & 0.037 & 0.046 & 0.046 \\
\hline Sweetwater & 0.017 & 0.015 & 0.086 & 0.104 & 0.057 & 0.054 & 0.125 & 0.112 & 0.231 & 0.057 & 0.071 & 0.071 \\
\hline Washakie & 0.030 & 0.027 & 0.152 & 0.184 & 0.101 & 0.095 & 0.077 & 0.069 & 0.142 & 0.035 & 0.044 & 0.044 \\
\hline \multicolumn{13}{|c|}{ Nitrogen Solutions } \\
\hline Albany & 0.048 & 0.043 & 0.243 & 0.294 & 0.161 & 0.152 & 0.011 & 0.010 & 0.020 & 0.005 & 0.006 & 0.006 \\
\hline Big Horn & 0.024 & 0.022 & 0.124 & 0.150 & 0.083 & 0.078 & 0.097 & 0.087 & 0.180 & 0.044 & 0.055 & 0.056 \\
\hline Fremont & 0.027 & 0.025 & 0.137 & 0.166 & 0.091 & 0.086 & 0.088 & 0.079 & 0.162 & 0.040 & 0.050 & 0.050 \\
\hline Goshen & 0.033 & 0.030 & 0.170 & 0.206 & 0.113 & 0.107 & 0.064 & 0.057 & 0.118 & 0.029 & 0.036 & 0.037 \\
\hline Laramie & 0.031 & 0.028 & 0.158 & 0.191 & 0.105 & 0.099 & 0.073 & 0.065 & 0.134 & 0.033 & 0.041 & 0.042 \\
\hline Park & 0.023 & 0.021 & 0.119 & 0.144 & 0.079 & 0.075 & 0.101 & 0.090 & 0.186 & 0.046 & 0.057 & 0.058 \\
\hline Platte & 0.027 & 0.024 & 0.136 & 0.164 & 0.091 & 0.086 & 0.089 & 0.079 & 0.163 & 0.040 & 0.050 & 0.051 \\
\hline Sheridan & 0.000 & 0.000 & 0.000 & 0.000 & 0.000 & 0.000 & 0.188 & 0.168 & 0.346 & 0.085 & 0.106 & 0.107 \\
\hline Sublette & 0.041 & 0.037 & 0.207 & 0.251 & 0.138 & 0.130 & 0.037 & 0.033 & 0.068 & 0.017 & 0.021 & 0.021 \\
\hline Washakie & 0.018 & 0.017 & 0.093 & 0.112 & 0.062 & 0.058 & 0.120 & 0.108 & 0.222 & 0.055 & 0.068 & 0.069 \\
\hline \multicolumn{13}{|c|}{ Monoammonium Phosphate } \\
\hline Albany & 0.027 & 0.025 & 0.137 & 0.166 & 0.091 & 0.086 & 0.088 & 0.079 & 0.162 & 0.040 & 0.049 & 0.050 \\
\hline Big Horn & 0.024 & 0.022 & 0.121 & 0.147 & 0.081 & 0.076 & 0.099 & 0.089 & 0.183 & 0.045 & 0.056 & 0.057 \\
\hline Carbon & 0.050 & 0.046 & 0.258 & 0.312 & 0.172 & 0.162 & 0.000 & 0.000 & 0.000 & 0.000 & 0.000 & 0.000 \\
\hline Fremont & 0.019 & 0.018 & 0.099 & 0.120 & 0.066 & 0.062 & 0.116 & 0.104 & 0.213 & 0.052 & 0.065 & 0.066 \\
\hline Goshen & 0.034 & 0.031 & 0.174 & 0.211 & 0.116 & 0.109 & 0.061 & 0.055 & 0.112 & 0.028 & 0.034 & 0.035 \\
\hline Johnson & 0.050 & 0.046 & 0.258 & 0.312 & 0.172 & 0.162 & 0.000 & 0.000 & 0.000 & 0.000 & 0.000 & 0.000 \\
\hline Laramie & 0.027 & 0.025 & 0.138 & 0.167 & 0.092 & 0.087 & 0.087 & 0.078 & 0.161 & 0.040 & 0.049 & 0.050 \\
\hline Park & 0.036 & 0.033 & 0.185 & 0.223 & 0.123 & 0.116 & 0.053 & 0.048 & 0.098 & 0.024 & 0.030 & 0.030 \\
\hline Platte & 0.031 & 0.028 & 0.157 & 0.191 & 0.105 & 0.099 & 0.073 & 0.065 & 0.135 & 0.033 & 0.041 & 0.042 \\
\hline Sheridan & 0.025 & 0.023 & 0.129 & 0.156 & 0.086 & 0.081 & 0.094 & 0.084 & 0.173 & 0.043 & 0.053 & 0.054 \\
\hline Sublette & 0.051 & 0.046 & 0.258 & 0.312 & 0.172 & 0.162 & 0.000 & 0.000 & 0.000 & 0.000 & 0.000 & 0.000 \\
\hline Sweetwater & 0.050 & 0.046 & 0.258 & 0.312 & 0.172 & 0.162 & 0.000 & 0.000 & 0.000 & 0.000 & 0.000 & 0.000 \\
\hline Uinta & 0.034 & 0.032 & 0.176 & 0.213 & 0.117 & 0.110 & 0.060 & 0.053 & 0.110 & 0.027 & 0.034 & 0.034 \\
\hline
\end{tabular}


Appendix D

\begin{tabular}{|c|c|c|c|c|c|c|c|c|c|c|c|c|}
\hline COUNTY & JAN & FEB & MAR & APR & MAY & JUN & JUL & AUG & SEP & OCT & NOV & DEC \\
\hline Washakie & 0.026 & 0.024 & 0.135 & 0.163 & 0.090 & 0.085 & 0.089 & 0.080 & 0.165 & 0.041 & 0.050 & 0.051 \\
\hline \multicolumn{13}{|l|}{ Mix } \\
\hline Albany & 0.035 & 0.032 & 0.177 & 0.214 & 0.118 & 0.111 & 0.059 & 0.053 & 0.109 & 0.027 & 0.033 & 0.034 \\
\hline Big Horn & 0.031 & 0.028 & 0.159 & 0.192 & 0.106 & 0.099 & 0.072 & 0.065 & 0.133 & 0.033 & 0.041 & 0.041 \\
\hline Campbell & 0.044 & 0.040 & 0.225 & 0.272 & 0.150 & 0.142 & 0.024 & 0.021 & 0.044 & 0.011 & 0.013 & 0.014 \\
\hline Carbon & 0.008 & 0.007 & 0.042 & 0.050 & 0.028 & 0.026 & 0.157 & 0.141 & 0.290 & 0.071 & 0.089 & 0.090 \\
\hline Converse & 0.050 & 0.046 & 0.258 & 0.312 & 0.172 & 0.162 & 0.000 & 0.000 & 0.000 & 0.000 & 0.000 & 0.000 \\
\hline Fremont & 0.033 & 0.030 & 0.167 & 0.202 & 0.111 & 0.105 & 0.066 & 0.059 & 0.122 & 0.030 & 0.037 & 0.038 \\
\hline Goshen & 0.000 & 0.000 & 0.002 & 0.002 & 0.001 & 0.001 & 0.186 & 0.167 & 0.343 & 0.085 & 0.105 & 0.106 \\
\hline Hot Springs & 0.006 & 0.005 & 0.029 & 0.035 & 0.019 & 0.018 & 0.167 & 0.149 & 0.307 & 0.076 & 0.094 & 0.095 \\
\hline Laramie & 0.025 & 0.023 & 0.127 & 0.153 & 0.085 & 0.080 & 0.095 & 0.085 & 0.176 & 0.043 & 0.054 & 0.054 \\
\hline Natrona & 0.045 & 0.041 & 0.230 & 0.278 & 0.153 & 0.144 & 0.020 & 0.018 & 0.038 & 0.009 & 0.012 & 0.012 \\
\hline Park & 0.045 & 0.042 & 0.231 & 0.280 & 0.154 & 0.145 & 0.019 & 0.017 & 0.036 & 0.009 & 0.011 & 0.011 \\
\hline Platte & 0.051 & 0.046 & 0.258 & 0.312 & 0.172 & 0.162 & 0.000 & 0.000 & 0.000 & 0.000 & 0.000 & 0.000 \\
\hline Sheridan & 0.050 & 0.046 & 0.258 & 0.312 & 0.172 & 0.162 & 0.000 & 0.000 & 0.000 & 0.000 & 0.000 & 0.000 \\
\hline Sublette & 0.008 & 0.008 & 0.042 & 0.051 & 0.028 & 0.027 & 0.157 & 0.140 & 0.289 & 0.071 & 0.088 & 0.090 \\
\hline Sweetwater & 0.046 & 0.043 & 0.237 & 0.287 & 0.157 & 0.148 & 0.015 & 0.014 & 0.028 & 0.007 & 0.009 & 0.009 \\
\hline Teton & 0.013 & 0.012 & 0.069 & 0.084 & 0.046 & 0.043 & 0.138 & 0.123 & 0.254 & 0.062 & 0.078 & 0.078 \\
\hline Uinta & 0.042 & 0.039 & 0.216 & 0.262 & 0.144 & 0.136 & 0.030 & 0.027 & 0.056 & 0.014 & 0.017 & 0.017 \\
\hline Washakie & 0.009 & 0.008 & 0.044 & 0.053 & 0.029 & 0.027 & 0.156 & 0.139 & 0.288 & 0.071 & 0.088 & 0.089 \\
\hline Weston & 0.027 & 0.025 & 0.137 & 0.166 & 0.092 & 0.086 & 0.088 & 0.078 & 0.162 & 0.040 & 0.049 & 0.050 \\
\hline \multicolumn{13}{|c|}{ Miscellaneous } \\
\hline Albany & 0.034 & 0.031 & 0.174 & 0.211 & 0.116 & 0.110 & 0.061 & 0.054 & 0.112 & 0.028 & 0.034 & 0.035 \\
\hline Big Horn & 0.035 & 0.032 & 0.179 & 0.217 & 0.119 & 0.112 & 0.057 & 0.051 & 0.105 & 0.026 & 0.032 & 0.033 \\
\hline Campbell & 0.007 & 0.006 & 0.036 & 0.043 & 0.024 & 0.023 & 0.162 & 0.144 & 0.298 & 0.073 & 0.091 & 0.092 \\
\hline Converse & 0.000 & 0.000 & 0.000 & 0.000 & 0.000 & 0.000 & 0.188 & 0.168 & 0.346 & 0.085 & 0.106 & 0.107 \\
\hline Fremont & 0.050 & 0.046 & 0.257 & 0.313 & 0.172 & 0.162 & 0.000 & 0.000 & 0.000 & 0.000 & 0.000 & 0.000 \\
\hline Goshen & 0.024 & 0.022 & 0.120 & 0.146 & 0.080 & 0.075 & 0.100 & 0.090 & 0.185 & 0.045 & 0.056 & 0.057 \\
\hline Hot Springs & 0.000 & 0.000 & 0.000 & 0.000 & 0.000 & 0.000 & 0.188 & 0.168 & 0.346 & 0.085 & 0.106 & 0.107 \\
\hline Johnson & 0.000 & 0.000 & 0.000 & 0.000 & 0.000 & 0.000 & 0.188 & 0.168 & 0.346 & 0.085 & 0.106 & 0.107 \\
\hline Laramie & 0.002 & 0.002 & 0.011 & 0.014 & 0.008 & 0.007 & 0.180 & 0.160 & 0.331 & 0.081 & 0.101 & 0.103 \\
\hline Natrona & 0.037 & 0.034 & 0.190 & 0.230 & 0.127 & 0.119 & 0.049 & 0.044 & 0.091 & 0.022 & 0.028 & 0.028 \\
\hline Park & 0.043 & 0.039 & 0.219 & 0.267 & 0.146 & 0.138 & 0.028 & 0.025 & 0.051 & 0.013 & 0.016 & 0.016 \\
\hline Sheridan & 0.026 & 0.024 & 0.132 & 0.160 & 0.088 & 0.083 & 0.092 & 0.082 & 0.169 & 0.042 & 0.052 & 0.052 \\
\hline Sublette & 0.050 & 0.046 & 0.258 & 0.312 & 0.171 & 0.162 & 0.000 & 0.000 & 0.000 & 0.000 & 0.000 & 0.000 \\
\hline
\end{tabular}




\section{Appendix D}

\begin{tabular}{|c|c|c|c|c|c|c|c|c|c|c|c|c|}
\hline COUNTY & JAN & FEB & MAR & APR & MAY & JUN & JUL & AUG & SEP & OCT & NOV & DEC \\
\hline Sweetwater & 0.050 & 0.046 & 0.258 & 0.312 & 0.172 & 0.162 & 0.000 & 0.000 & 0.000 & 0.000 & 0.000 & 0.000 \\
\hline Teton & 0.043 & 0.039 & 0.218 & 0.264 & 0.145 & 0.137 & 0.029 & 0.026 & 0.053 & 0.013 & 0.016 & 0.016 \\
\hline Uinta & 0.034 & 0.031 & 0.173 & 0.209 & 0.115 & 0.108 & 0.062 & 0.055 & 0.114 & 0.028 & 0.035 & 0.035 \\
\hline Washakie & 0.042 & 0.038 & 0.212 & 0.257 & 0.141 & 0.133 & 0.033 & 0.030 & 0.061 & 0.015 & 0.019 & 0.019 \\
\hline Weston & 0.000 & 0.000 & 0.000 & 0.000 & 0.000 & 0.000 & 0.188 & 0.168 & 0.346 & 0.085 & 0.106 & 0.107 \\
\hline \multicolumn{13}{|c|}{ Liquid Ammonium Polyphosphate } \\
\hline Albany & 0.050 & 0.046 & 0.258 & 0.312 & 0.172 & 0.162 & 0.000 & 0.000 & 0.000 & 0.000 & 0.000 & 0.000 \\
\hline Carbon & 0.000 & 0.000 & 0.000 & 0.000 & 0.000 & 0.000 & 0.188 & 0.168 & 0.346 & 0.085 & 0.106 & 0.108 \\
\hline Fremont & 0.042 & 0.039 & 0.215 & 0.260 & 0.144 & 0.136 & 0.031 & 0.028 & 0.057 & 0.014 & 0.017 & 0.018 \\
\hline Goshen & 0.026 & 0.024 & 0.133 & 0.161 & 0.089 & 0.084 & 0.091 & 0.081 & 0.168 & 0.041 & 0.051 & 0.052 \\
\hline Laramie & 0.002 & 0.002 & 0.010 & 0.012 & 0.007 & 0.006 & 0.180 & 0.161 & 0.333 & 0.082 & 0.102 & 0.103 \\
\hline Natrona & 0.040 & 0.037 & 0.206 & 0.250 & 0.138 & 0.130 & 0.038 & 0.034 & 0.069 & 0.017 & 0.021 & 0.021 \\
\hline Park & 0.022 & 0.020 & 0.112 & 0.135 & 0.074 & 0.070 & 0.106 & 0.095 & 0.196 & 0.048 & 0.060 & 0.061 \\
\hline Platte & 0.000 & 0.000 & 0.000 & 0.000 & 0.000 & 0.000 & 0.188 & 0.168 & 0.346 & 0.085 & 0.106 & 0.107 \\
\hline Washakie & 0.029 & 0.027 & 0.149 & 0.180 & 0.099 & 0.094 & 0.080 & 0.071 & 0.146 & 0.036 & 0.045 & 0.045 \\
\hline \multicolumn{13}{|c|}{ Diammonium Phosphate } \\
\hline Big Horn & 0.035 & 0.032 & 0.177 & 0.213 & 0.118 & 0.111 & 0.059 & 0.053 & 0.109 & 0.027 & 0.033 & 0.034 \\
\hline Carbon & 0.000 & 0.000 & 0.000 & 0.000 & 0.000 & 0.000 & 0.188 & 0.168 & 0.346 & 0.085 & 0.106 & 0.107 \\
\hline Fremont & 0.029 & 0.027 & 0.148 & 0.179 & 0.099 & 0.093 & 0.080 & 0.071 & 0.147 & 0.036 & 0.045 & 0.046 \\
\hline Goshen & 0.026 & 0.023 & 0.131 & 0.158 & 0.087 & 0.082 & 0.093 & 0.083 & 0.171 & 0.042 & 0.052 & 0.053 \\
\hline Johnson & 0.000 & 0.000 & 0.000 & 0.000 & 0.000 & 0.000 & 0.188 & 0.168 & 0.346 & 0.085 & 0.106 & 0.107 \\
\hline Laramie & 0.000 & 0.000 & 0.000 & 0.000 & 0.000 & 0.000 & 0.188 & 0.168 & 0.345 & 0.085 & 0.106 & 0.107 \\
\hline Park & 0.031 & 0.028 & 0.157 & 0.190 & 0.105 & 0.098 & 0.074 & 0.066 & 0.136 & 0.033 & 0.041 & 0.042 \\
\hline Sheridan & 0.028 & 0.026 & 0.143 & 0.173 & 0.095 & 0.090 & 0.084 & 0.075 & 0.154 & 0.038 & 0.047 & 0.048 \\
\hline Washakie & 0.027 & 0.024 & 0.135 & 0.163 & 0.090 & 0.085 & 0.089 & 0.080 & 0.165 & 0.040 & 0.050 & 0.051 \\
\hline \multicolumn{13}{|c|}{ Calcium Ammonium Nitrate } \\
\hline Park & 0.050 & 0.046 & 0.258 & 0.312 & 0.172 & 0.162 & 0.000 & 0.000 & 0.000 & 0.000 & 0.000 & 0.000 \\
\hline \multicolumn{13}{|c|}{ Aqueous Ammonia } \\
\hline Goshen & 0.000 & 0.000 & 0.000 & 0.000 & 0.000 & 0.000 & 0.188 & 0.168 & 0.346 & 0.085 & 0.106 & 0.107 \\
\hline \multicolumn{13}{|c|}{ Anhydrous Ammonia } \\
\hline Fremont & 0.034 & 0.031 & 0.172 & 0.209 & 0.115 & 0.108 & 0.062 & 0.055 & 0.115 & 0.028 & 0.035 & 0.036 \\
\hline Goshen & 0.030 & 0.028 & 0.154 & 0.187 & 0.103 & 0.097 & 0.075 & 0.067 & 0.139 & 0.034 & 0.042 & 0.043 \\
\hline Laramie & 0.016 & 0.015 & 0.081 & 0.099 & 0.054 & 0.051 & 0.128 & 0.115 & 0.237 & 0.058 & 0.072 & 0.073 \\
\hline Park & 0.050 & 0.046 & 0.258 & 0.312 & 0.172 & 0.162 & 0.000 & 0.000 & 0.000 & 0.000 & 0.000 & 0.000 \\
\hline
\end{tabular}


Appendix D

\begin{tabular}{|c|c|c|c|c|c|c|c|c|c|c|c|c|}
\hline COUNTY & JAN & FEB & MAR & APR & MAY & JUN & JUL & AUG & SEP & OCT & NOV & DEC \\
\hline Platte & 0.050 & 0.046 & 0.255 & 0.308 & 0.170 & 0.160 & 0.002 & 0.002 & 0.004 & 0.001 & 0.001 & 0.001 \\
\hline Sweetwater & 0.028 & 0.026 & 0.144 & 0.175 & 0.097 & 0.091 & 0.082 & 0.074 & 0.152 & 0.037 & 0.046 & 0.047 \\
\hline Washakie & 0.025 & 0.023 & 0.126 & 0.153 & 0.084 & 0.079 & 0.096 & 0.086 & 0.177 & 0.043 & 0.054 & 0.055 \\
\hline \multicolumn{13}{|c|}{ Ammonium Thiosulfate } \\
\hline Big Horn & 0.048 & 0.044 & 0.242 & 0.294 & 0.162 & 0.153 & 0.011 & 0.010 & 0.020 & 0.005 & 0.006 & 0.006 \\
\hline Campbell & 0.050 & 0.046 & 0.258 & 0.312 & 0.172 & 0.162 & 0.000 & 0.000 & 0.000 & 0.000 & 0.000 & 0.000 \\
\hline Converse & 0.000 & 0.000 & 0.000 & 0.000 & 0.000 & 0.000 & 0.188 & 0.168 & 0.346 & 0.085 & 0.106 & 0.107 \\
\hline Goshen & 0.030 & 0.027 & 0.151 & 0.183 & 0.101 & 0.095 & 0.077 & 0.069 & 0.143 & 0.035 & 0.044 & 0.044 \\
\hline Johnson & 0.000 & 0.000 & 0.000 & 0.000 & 0.000 & 0.000 & 0.188 & 0.168 & 0.346 & 0.085 & 0.106 & 0.107 \\
\hline Laramie & 0.024 & 0.022 & 0.121 & 0.146 & 0.080 & 0.076 & 0.100 & 0.089 & 0.184 & 0.045 & 0.056 & 0.057 \\
\hline Park & 0.041 & 0.037 & 0.207 & 0.251 & 0.138 & 0.130 & 0.037 & 0.033 & 0.068 & 0.017 & 0.021 & 0.021 \\
\hline Sublette & 0.050 & 0.046 & 0.258 & 0.312 & 0.171 & 0.162 & 0.000 & 0.000 & 0.000 & 0.000 & 0.000 & 0.000 \\
\hline Washakie & 0.036 & 0.033 & 0.184 & 0.223 & 0.122 & 0.116 & 0.054 & 0.048 & 0.099 & 0.024 & 0.030 & 0.031 \\
\hline \multicolumn{13}{|c|}{ Ammonium Sulfate } \\
\hline Fremont & 0.028 & 0.026 & 0.143 & 0.173 & 0.095 & 0.090 & 0.084 & 0.075 & 0.154 & 0.038 & 0.047 & 0.048 \\
\hline Goshen & 0.041 & 0.038 & 0.211 & 0.255 & 0.141 & 0.132 & 0.034 & 0.031 & 0.063 & 0.015 & 0.019 & 0.019 \\
\hline Laramie & 0.044 & 0.040 & 0.225 & 0.272 & 0.149 & 0.141 & 0.024 & 0.022 & 0.044 & 0.011 & 0.014 & 0.014 \\
\hline Park & 0.029 & 0.027 & 0.149 & 0.180 & 0.099 & 0.093 & 0.079 & 0.071 & 0.146 & 0.036 & 0.045 & 0.045 \\
\hline Sheridan & 0.033 & 0.030 & 0.169 & 0.204 & 0.112 & 0.106 & 0.065 & 0.058 & 0.120 & 0.029 & 0.037 & 0.037 \\
\hline Sweetwater & 0.000 & 0.000 & 0.000 & 0.000 & 0.000 & 0.000 & 0.188 & 0.168 & 0.346 & 0.085 & 0.106 & 0.108 \\
\hline Uinta & 0.030 & 0.028 & 0.155 & 0.188 & 0.103 & 0.097 & 0.075 & 0.067 & 0.138 & 0.034 & 0.042 & 0.043 \\
\hline Washakie & 0.050 & 0.046 & 0.258 & 0.312 & 0.172 & 0.162 & 0.000 & 0.000 & 0.000 & 0.000 & 0.000 & 0.000 \\
\hline \multicolumn{13}{|c|}{ Ammonium Nitrate } \\
\hline Albany & 0.045 & 0.042 & 0.231 & 0.280 & 0.154 & 0.145 & 0.019 & 0.017 & 0.035 & 0.009 & 0.011 & 0.011 \\
\hline Big Horn & 0.033 & 0.030 & 0.167 & 0.202 & 0.111 & 0.105 & 0.066 & 0.059 & 0.122 & 0.030 & 0.037 & 0.038 \\
\hline Carbon & 0.045 & 0.041 & 0.231 & 0.280 & 0.154 & 0.145 & 0.020 & 0.018 & 0.036 & 0.009 & 0.011 & 0.011 \\
\hline Fremont & 0.028 & 0.026 & 0.145 & 0.175 & 0.096 & 0.091 & 0.082 & 0.074 & 0.152 & 0.037 & 0.046 & 0.047 \\
\hline Goshen & 0.047 & 0.043 & 0.240 & 0.291 & 0.160 & 0.151 & 0.013 & 0.012 & 0.024 & 0.006 & 0.007 & 0.007 \\
\hline Johnson & 0.000 & 0.000 & 0.000 & 0.000 & 0.000 & 0.000 & 0.188 & 0.168 & 0.346 & 0.085 & 0.106 & 0.107 \\
\hline Laramie & 0.039 & 0.036 & 0.198 & 0.240 & 0.132 & 0.124 & 0.044 & 0.039 & 0.080 & 0.020 & 0.025 & 0.025 \\
\hline Lincoln & 0.050 & 0.046 & 0.258 & 0.312 & 0.172 & 0.162 & 0.000 & 0.000 & 0.000 & 0.000 & 0.000 & 0.000 \\
\hline Natrona & 0.000 & 0.000 & 0.000 & 0.000 & 0.000 & 0.000 & 0.188 & 0.168 & 0.346 & 0.085 & 0.106 & 0.107 \\
\hline Park & 0.037 & 0.034 & 0.188 & 0.227 & 0.125 & 0.118 & 0.051 & 0.046 & 0.094 & 0.023 & 0.029 & 0.029 \\
\hline Platte & 0.050 & 0.046 & 0.258 & 0.311 & 0.172 & 0.162 & 0.000 & 0.000 & 0.000 & 0.000 & 0.000 & 0.000 \\
\hline Sheridan & 0.026 & 0.024 & 0.131 & 0.159 & 0.087 & 0.082 & 0.092 & 0.083 & 0.170 & 0.042 & 0.052 & 0.053 \\
\hline
\end{tabular}


Appendix D

\begin{tabular}{lcccccccccccc}
\hline COUNTY & JAN & FEB & MAR & APR & MAY & JUN & JUL & AUG & SEP & OCT & NOV & DEC \\
\hline Sublette & 0.050 & 0.046 & 0.258 & 0.313 & 0.172 & 0.162 & 0.000 & 0.000 & 0.000 & 0.000 & 0.000 & 0.000 \\
Sweetwater & 0.051 & 0.046 & 0.258 & 0.312 & 0.172 & 0.162 & 0.000 & 0.000 & 0.000 & 0.000 & 0.000 & 0.000 \\
Uinta & 0.031 & 0.028 & 0.156 & 0.189 & 0.104 & 0.098 & 0.074 & 0.066 & 0.136 & 0.034 & 0.042 & 0.042 \\
Washakie & 0.033 & 0.031 & 0.170 & 0.207 & 0.113 & 0.107 & 0.063 & 0.057 & 0.117 & 0.029 & 0.036 & 0.036 \\
\hline
\end{tabular}

